\title{
PREJUDIS KEAGAMAAN: KESENGSARAAN MASYARAKAT ROHINGYA DI MYANMAR
}

\author{
Azharudin Md Dali
}

\begin{abstract}
From a historical perspective, the Rohingyas in Myanmar could be regarded as among the most victimized community in the world. Compared to others Muslim minorities in the region such as the ethnic Moro in southern Philippines or Muslim communities in southern Thailand, the Rohingya's existence, their civic status and their personal narratives are rarely examined and exposed. The Rohingya Muslim community in Myanmar is burdened with continued persecution and suffering. This occurs due to the Myanmar government's refusal to recognise and provide citizenship status to the Rohingya leading to an endless problem of identity. This article seeks to reveal the plight of the Rohingya people, including in matters of religion, as well as the history of the Rohingya people. It argues that the biggest challenge to the Rohingya people in Myanmar is religious prejudice, a problem serious enough to drive them to flee their homes. The Rohingyas now could be found in various countries including Malaysia, Thailand and Bangladesh as well as European countries and the United States of America.
\end{abstract}

\section{Pengenalan}

Seorang penulis, Graham E. Fuller dalam bukunya A World Without Islam yang diterbitkan pada 2010 ada menyentuh mengenai kepentingan dan kekuatan agama kepada manusia. Antara lain, Graham E. Fuller menegaskan betapa berkuasanya agama dalam kehidupan manusia. Ini kerana, agama bukan sahaja mampu menentukan kehidupan dan kematian tetapi juga mengenai peperangan, perbuatan moral, 
kemasyarakatan, sifat seksual, psikologi malah perbuatan manusia. Lebih penting lagi, agama bukan sahaja bersifat perseorangan sebaliknya membabitkan keseluruhan masyarakat yang mempunyai pegangan agama sama dan agama juga menjadi asas kekuatan sesebuah masyarakat. Memahami mengenai penegasan Fuller secara langsung mendedahkan kita mengenai kepentingan agama sehingga perbezaan agama turut menjadi asas dalam pertelingkahan antara manusia. Hal ini berlaku di Myanmar apabila sifat prejudis yang ekstrim oleh penganut agama Buddha yang turut didokong oleh mekanisma negara menjadikan orang Islam umumnya dan orang Rohingya khasnya sebagai sasaran mereka.

Myanmar dikenali sebagai sebuah negara yang bersifat multi-etnik dan multi-agama. Malahan terdapat pengkaji yang menyatakan bahawa wujudnya masyarakat majmuk yang cukup jelas di Myanmar. Selain itu, salah satu ciri Myanmar yang sangat ketara adalah perkaitannya yang erat dengan agama Buddha terutama Buddha Theravada. Ini bermakna, dalam konteks Asia Tenggara, Myanmar merupakan antara negara yang menjadikan agama Buddha sebagai teras penting dalam masyarakat dan negara selain Thailand dan negara-negara Indochina seperti Laos, Vietnam dan Cambodia. Asas-asas agama Buddha menjadi pegangan dalam masyarakat dan turut menjadi 'agama negara'. Agama Buddha Theravada menjadi amalan hidup yang penting bagi masyarakat di Myanmar. Kedudukan agama Buddha telah mengukuh dalam masyarakat sejak sekian lama dan membentuk konsep-konsep sosiopolitik di Myanmar hingga membayangkan satu hubungan intim antara institusi raja dengan sangha Buddha.

Dalam konteks Islam, Myanmar yang terletak dalam laluan perdagangan timur-barat turut menerima kehadiran pedagangpedagang Islam yang pernah menguasai laluan ini sejak abad ke-9 hingga abad ke-15. Melalui perdagangan, aktiviti perkembangan Islam turut berlaku. Sejajar dengan kedudukan Myanmar yang berhampiran dengan benua kecil India, maka perkembangan-perkembangan yang berlaku di situ turut mempengaruhi Myanmar. Keadaan ini semakin ketara apabila Islam bertapak di Bengal dan ini secara langsung mewujudkan kerajaan-kerajaan Islam dan berkembang sehingga ke Myanmar. Daripada perkembangan inilah yang kemudiannya melahirkan kerajaan Islam di Myanmar.

Kedudukan masyarakat Islam sebagai masyarakat minoriti yang dikelilingi golongan majoriti bukanlah sesuatu yang asing dalam konteks sejarah Asia Tenggara. Negara-negara seperti Thailand, Laos, Vietnam dan Cambodia turut mengalami hal yang sama. Meskipun masyarakat Islam di Cambodia, Vietnam mahupun Laos tidaklah mengalami kehidupan yang sukar seperti saudara mereka di Myanmar 
mahupun Thailand namun kesukarannya masih dirasakan. Ketika masyarakat Islam di Myanmar menghadapi pemerintahan junta tentera, masyarakat Islam di selatan Thailand berada dalam darjah kesukaran yang berbeza. Didapati sebahagian saudara mereka di Thailand mengambil jalan agak ekstrim dengan menggunakan senjata dan bom tangan sebagai satu bentuk tindakan anti-kerajaan. Manakala masyarakat Islam di Myanmar pula mengambil langkah sebaliknya apabila masih mengharapkan satu bentuk sistem pemerintahan yang lebih baik dan dapat menerima mereka di Myanmar. Sebahagiannya tidak sanggup menghadapi tekanan dan kesukaran yang dilakukan oleh pihak pemerintah secara langsung menyebabkan mereka menjadi pelarian.

\section{Agama dan Masyarakat Myanmar}

Dari sudut geografi, Myanmar atau sebelum ini dikenali sebagai Burma terletak di antara wilayah Bangladesh dan India di bahagian barat, Tibet di bahagian utara sementara Yunnan, Thailand dan Indochina di bahagian timur. Di bahagian selatan pula, Myanmar terletak berhampiran dengan Semenanjung Malaysia dan Sumatera. Secara keseluruhannya, Myanmar dibahagikan kepada empat kawasan utama iaitu Dataran Tinggi Shan, Lembah Irrawady, Jajaran Banjaran Utara dan Kawasan Pantai Arakan. Latar geografi dan situasi ini mempengaruhi latar belakang ekonomi dan kehidupan penduduknya. Misalnya, kawasan Lembah Irrawady yang subur merupakan kawasan pertanian utama sementara kawasan pantai Arakan pula merupakan kawasan penting untuk aktiviti perdagangan, perikanan dan pertanian serta menjadi pusat petempatan manusia dan pusat kerajaan sejak sekian lama. ${ }^{1}$

Berdasarkan perangkaan pada 1826, jumlah penduduk Myanmar ialah 4 juta orang. Pada 1891, jumlah penduduk ialah 7.7juta. Penduduk Myanmar semakin meningkat pada 1911 iaitu seramai 12 juta orang dan pada 1921 pula menjadi 13.2 juta orang. Pada 1931, penduduk Myanmar ialah 14.6juta sementara pada 1941 pula ialah 16.8 juta orang dan merupakan antara wilayah jajahan British yang padat penduduknya jika dibandingkan dengan tanah-tanah jajahan lain seperti Tanah Melayu sebelum Perang Dunia Kedua (PD 2). Dua wilayah yang padat penduduknya di Myanmar ialah Arakan dan Tenasserim iaitu 294,000 orang pada 1835 sementara pada 1850, kedua-dua wilayah mempunyai penduduk berjumlah 586,000 orang. ${ }^{2}$ Sebahagian besar penduduk terdiri dari penduduk luar bandar yang menjalankan aktiviti pertanian dan perikanan sebagai aktiviti ekonomi utama. Jumlah penduduk di Rangoon iaitu bandar utama di Myanmar dalam era sebelum PD 2 ialah 
500,000 orang diikuti oleh Mandalay kira-kira 163,000 orang. Bandarbandar lain pula hanya mempunyai penduduk antara 20,000 hingga 70,000 orang. ${ }^{3}$ Berdasarkan keadaan ini, maka jelas sebahagian besar penduduk Myanmar dalam era sebelum perang merupakan penduduk luar bandar.

Myanmar merupakan negara yang mempunyai pelbagai kumpulan etnik dan secara umumnya boleh dibahagikan kepada tiga kumpulan utama iaitu Tibeto-Burman, Mon-Khmer dan Tai-China. Kelompok yang termasuk dalam kategori Tibeto-Burman dipecahkan kepada tiga sub-kumpulan iaitu Burma dan proto-Burma, Chin-Kachin dan Lolo. Bagi kumpulan Mon-Khmer pula terdiri dalam kalangan Mon, Palaung, Yimbau dan sebagainya. Kumpulan Tai-China pula terdiri daripada orang Shan, Karen, Hkun, Lao dan sebagainya. ${ }^{4}$ Dalam masa yang sama, dalam kalangan orang etnologi yang melakukan kajian mengenai kumpulan etnik ini mempunyai pelbagai pandangan mengenai kelompok etnik serta kedudukan mereka. Dalam usaha mengenal pasti kumpulan etnik utama maka beberapa pembahagian telah dilakukan berdasarkan keutamaan kumpulan. Kumpulan pertama ialah orang Burman. Pada tempoh sebelum PD 2, orang Burman didapati bertumpu di zon yang dikenali sebagai Myanmar Tengah dan mereka dikatakan bertanggungjawab dalam membentuk kerajaan-kerajaan silam di Myanmar seperti Pagan, Ava, Amarapura, Mandalay dan sebagainya.

Pada abad ke-11, beberapa kerajaan kecil Burman telah disatukan oleh Raja Anawartha yang membentuk kerajaannya berpusat di Pagan. Beliau juga telah meluaskan kerajaannya ke Lembah Irrawady sehingga ke Lembah Sittang. Raja Anawartha juga bertanggungjawab untuk memperkenal dan menyebarkan agama Buddha Hinayana bagi menggantikan Buddha Mahayana yang disifatkan sebagai 'kurang asli' . Bandar Pagan kekal sebagai pusat kerajaan hingga abad ke-13 sebelum dimusnahkan oleh serangan orang Mongol. Penggunaan istilah Burman tidak sedikit melahirkan kontroversi. Ini berlaku apabila Burman digunakan untuk merujuk kelompok majoriti sementara 'Burmese' pula digunakan untuk merujuk etnik lain. Hampir 70 peratus daripada penduduk Myanmar ialah orang Burman. Kelompok minoriti terbesar pula ialah orang Shan. ${ }^{5}$

Dalam aspek keagamaan, agama Buddha Theravada merupakan agama utama diikuti dengan agama-agama lain termasuk Kristian, Islam dan sebagainya. Berdasarkan sejarah, didapati pada 1931, daripada 14.6 juta penduduk Myanmar didapati kira-kira 12.3 juta atau 84 peratus ialah penganut agama Buddha. Manakala seramai 763,243 atau 5.2 peratus pula ialah animism diikuti dengan 570,953 atau 3.9 peratus agama Hindu dan 584,839 atau 4 peratus beragama Islam, 331,106 atau 2.3 peratus pula beragama Kristian dan selebihnya adalah lain-lain 
agama. Dari sudut pecahan etnik pula, orang Burman, Kuki-Chan dan Karen didapati menganut agama Buddha, Animisma dan Kristian. Etnik Kachin lebih mengamalkan Animisma dan Kristian sementara orang Shan secara keseluruhannya beragama Buddha. Dalam kategori orang India pula sebahagian besarnya beragama Hindu diikuti dengan agama Islam, Kristian dan Buddha. Selain itu, kira-kira 1,474 orang Cina merupakan orang Islam diikuti seramai 43,399 menganut agama Buddha dan 1,466 agama Kristian. Dalam kategori kaum beragama Islam, ini juga seramai 186, 861 orang diletakkan dalam kategori beragama Islam hingga jumlah keseluruhan orang Islam di Myanmar pada 1931 ialah 584, 839 orang. ${ }^{6}$

Agama Buddha membentuk sudut pandang dan amalan dalam kehidupan harian. Keadaan ini jelas berlaku apabila pelbagai peraturan yang wujud dalam agama Buddha menjadi 'peraturan' seperti larangan untuk membunuh semua makhluk bernyawa sama ada manusia mahupun haiwan. Malahan, menurut Abu Talib perkataan "bunuh" untuk haiwan harus dielakkan penggunaannya sebaliknya diganti dengan perkataan yang lebih sesuai seperti ikan tidak dibunuh untuk dimakan tetapi disebut sebagai "mengeluarkannya dari tempat kehidupan semulajadinya" dan sebagainya. ${ }^{7}$ Walau bagaimanapun, secara realiti terdapat amalan yang berbeza dengan pandangan ini. Penentangan yang berlaku terhadap kerajaan menyebabkan pembunuhan dan kekerasan seringkali dilakukan. Golongan yang dianggap sebagai pemberontak sama ada orang Karen, Chin mahupun Kachin ditembak oleh pihak berkuasa. Hal yang sama berlaku terhadap penganut agama Islam seperti Rohingya yang turut menerima kesan dari kekejaman yang berlaku. Abu Talib Ahmad sewaktu melihat kekuatan pengaruh Buddha Theravada dalam masyarakat Myanmar menyatakan:

Pengaruh Buddhisme berkait rapat dengan kehidupan manusia dan bagi Burma [Myanmar], pengaruh ini membuatkan rakyatnya bersikap pragmatik dan realistik terhadap kehidupan. Di samping itu, mereka juga mahukan warisan tradisi dikekalkan, malah diperkukuhkan. Pengaruh Buddhisme ini juga berkaitan dengan kebebasan individu dan lanjutannya, kebebasan sebuah negara Burma [Myanmar] seperti yang berlaku pada zaman silam. ${ }^{8}$

\section{Kehadiran Islam}

Islam merupakan agama minoriti di Myanmar. Sejarah kehadiran Islam telah bermula sekurang-kurangnya pada abad ke-8 dan abad ke-9 Masihi. Kehadiran Islam ke Myanmar mempunyai ikatan dengan perkembangan Islam dari India. T. W. Arnold menyatakan bahawa pedagang Islam dari India telah menyebarkan Islam ke Myanmar. ${ }^{9}$ Dari 
pusat perdagangan di sepanjang pesisiran Benua Kecil India terutama dari Bengal dan Malabar, pedagang-pedagang Islam memberikan tumpuan kepada aktiviti perdagangan di sepanjang pesisiran pantai Myanmar terutamanya di Arakan dan kawasan hilir Myanmar. Catatan pedagang dan pengembara Islam sama ada dari Arab mahupun Parsi sekitar abad ke-9 dan abad ke-10 seperti Ibn Khordadhbeh, Sulaiman, Ibn al-Faqih dan al-Maqdisi yang melalui laluan Teluk Bengala-Selat Melaka telah mencatatkan mengenai aktiviti perdagangan Islam di pesisiran pantai Myanmar. Pada tempoh ini, pedagang Islam dipastikan telah biasa dan mengenali perairan Myanmar termasuklah pusat perdagangan mahupun persinggahan kapal-kapal dagang seperti pantai Arakan, Delta Irrawady, Pegu dan Tenasserim. Keadaan ini dijelaskan melalui adanya penempatan orang Islam di sekitar Pegu pada abad ke-9 Masihi. ${ }^{10}$

Kepentingan perdagangan ini bukan sekadar melalui jalan laut tetapi juga membabitkan jalan darat. Myanmar menjadi laluan perdagangan daratan penting yang membabitkan laluan MyanmarChina melalui Yunnan. Laluan ini sangat dikenali sekitar abad ke-9 sehingga abad-12 kerana sumber mineral dan batuan yang berharga termasuk emas. Emas menjadi komoditi perdagangan penting kerana permintaan yang sangat tinggi memasuki pasaran di Bengal melalui Assam dan bahagian daratan Myanmar. Selain emas, mineral yang berharga termasuklah perak yang diperolehi dari bahagian timur Myanmar. Bahan dagangan ini akan dibawa ke India melalui bahagian daratan Myanmar sebelum menghilir melalui Arakan yang menjadi 'transfer-point' sebelum memasuki Bengal. Laluan ini merupakan antara laluan utama diikuti kemudiannya dengan beberapa laluan lain yang memasuki pasaran India melalui Manipur mahupun Nepal dan Tibet. ${ }^{11}$ Arakan dan Pegu turut penting dalam melihat laluan perdagangan dari arah India ke Alam Melayu selain bertindak sebagai pusat perdagangan. Kedua-duanya memainkan peranan penting dalam proses permindahan agama dan budaya. ${ }^{12}$

Salah satu ciri yang jelas dalam memperkatakan mengenai kehadiran pedagang-pedagang Islam di rantau Asia Tenggara ialah perkahwinan mereka dengan wanita tempatan. Aktiviti perdagangan yang dijalankan oleh pedagang Islam sama ada dari Arab, Parsi mahupun India merupakan aktiviti yang dilihat memerlukan ketahanan diri yang cukup ampuh hingga akhirnya hanya orang lelaki sahaja yang terbabit dalam aktiviti ini. Sebahagian mereka akan menetap agak lama di pelabuhan ketika menanti peralihan angin dan dalam tempoh inilah mereka akan berkahwin dengan wanita tempatan. Selain itu, sebahagian mereka pula terkandas kerana kapal mereka karam atau rosak dan perlu diperbaiki sehingga menyebabkan mereka berada lama 
di pelabuhan yang disinggahi. Dalam situasi inilah perkahwinan dengan wanita tempatan terjalin dan komuniti Islam mula berlaku. Keadaan yang sama turut berlaku di Myanmar dan di antara pedagang Islam yang dikatakan terdampar di pantai Martaban akibat kapal tumpangan mereka karam sekitar abad ke-11 ketika zaman pemerintahan Raja Anawratha ialah Shwepyin-nge dan Shwepyin-gyi. ${ }^{13}$ Mereka dikatakan pernah berkhidmat dalam pasukan berkuda tentera raja Anawratha namun telah dihukum bunuh kerana enggan mematuhi arahan raja untuk membina sebuah biara. Malahan orang Myanmar percaya bahawa roh mereka masih berada di biara tersebut dan sebagai satu bentuk penghormatan, ketika upacara keagamaan di perkarangan biara tersebut, makanan yang mengandungi daging babi tidak akan dihidangkan. ${ }^{14}$

Pada zaman pemerintahan Raja Sawlu iaitu antara 1077 hingga 1088 Masihi pula, terdapat catatan menyebut mengenai konflik politik membabitkan komuniti Arab. Raja Sawlu dikatakan mempunyai hubungan yang baik dengan seorang guru berbangsa Arab. Hubungan ini diperkukuhkan kemudiannya apabila anak guru ini bernama Yaman Khan atau Abdul Rahman telah dilantik sebagai gabenor di Pegu. Walau bagaimanapun, berlaku pertelingkahan politik hingga menyebabkan Yaman Khan membunuh Raja Sawlu namun beliau sendiri dibunuh oleh anak Raja Sawlu bernama Kyanzittha. ${ }^{15}$ Dalam masa yang sama, perkhidmatan tentera-tentera Islam turut digunakan oleh raja-raja Mon terutamanya dalam pasukan meriam dan mereka terbabit dalam peperangan antara orang Mon dan Burman pada abad ke-15 masihi. Sebahagian mereka kemudiannya menjadi tawanan perang dan ditempatkan di Myanmar hulu. ${ }^{16}$

Pada 1404, Arakan telah diserang oleh kerajaan Ava hingga menyebabkan raja Arakan, Narameikhla terpaksa melarikan diri ke Bengal untuk mendapatkan perlindungan politik di samping mengumpulkan kekuatan. Pada 1430, sebaik sahaja merasakan kekuatannya telah pulih, beliau telah kembali ke Arakan dan berjaya menumpaskan orang Ava. Beliau menubuhkan pusat pemerintahan di Mrauk-U (Mrohaung). Kemenangan Narameikhla diperoleh setelah mendapat bantuan dari tentera Islam yang seterusnya turut menjadi pencetus kepada pembabitan Islam dalam intrik politik di Arakan. Tentera-tentera Islam ini kemudiannya membentuk komuniti Islam di Mrauk-U dan sebagai lambang adanya kewujudan mereka, sebuah masjid telah dibina. Masjid ini dinamakan Masjid Schandhikan yang merupakan masjid tertua di Myanmar yang terus digunakan sehingga 1940-an. ${ }^{17}$

Dalam tempoh antara abad ke-14 hingga abad ke-17, sepanjang pesisiran pantai Myanmar pesat dengan aktiviti perdagangan yang 
dijalankan oleh pedagang-pedagang Islam. Jumlah mereka juga bertambah sejajar dengan kedudukan pedagang Islam sebagai penguasa laluan perdagangan antara timur dan barat. Pelabuhan Pegu, Dela, Cirion, Tenasserim dan Mergui dipenuhi dengan pedagang-pedagang Islam. Malahan pelabuhan Martaban dilihat sebagai kawasan utama yang menjadi tumpuan pedagang Islam. Aktiviti perdagangan ini membabitkan komoditi seperti gula, batu permata (delima), kapas, sutera, candu, tembaga, perak, herba dan ubata-ubatan. ${ }^{18}$

Dalam masa yang sama, peperangan-peperangan yang berlaku di Myanmar sepanjang tempoh tersebut menyebabkan suburnya aktiviti perhambaan yang terdiri dalam kalangan orang Islam dan Kristian. Setelah ditawan, mereka akan ditempatkan di beberapa kawasan Pegu, Arakan, Tennaserim dan sebagainya. Ada di antara mereka dibenarkan untuk mengamalkan cara hidup mereka termasuklah amalan keagamaan dengan syarat amalan tersebut tidak disebarkan. Menurut Abu Talib Ahmad, sehingga lewat 1940-an dan 1950-an, masih terdapat sebilangan besar orang Islam di bandar Yamethin dan Pyawbwe yang terletak di Myanmar hulu yang merupakan tawanan perang pada abad ke- $16 .{ }^{19}$

Pada abad ke-8 hingga abad ke-17, kehadiran Islam mempunyai kaitan langsung dengan aktiviti perdagangan. Namun perubahan berlaku pada abad ke-18 hingga abad ke-20 apabila pihak Barat mula menjadi kuasa yang dominan. Secara perlahan-lahan kuasa-kuasa Barat yang telah berjaya menguasai laluan perdagangan timur-barat mula berusaha untuk mendapatkan tanah-tanah jajahan. Bermula dengan negara-negara di Afrika, India dan akhirnya ke rantau Asia Tenggara. Myanmar tidak terlepas dari perhatian mereka dan kuasa British menjadi kuasa terpenting di Myanmar. Sebaik sahaja berjaya menguasai India terutama wilayah Bengal, perhatian British mula berpusat ke Myanmar hingga akhirnya berlakulah perang Anglo-Burma. Kesan daripada peperangan inilah yang menyebabkan Myanmar jatuh ke tangan British. Kehadiran kuasa British bukan sahaja mengubah senario untuk mempengaruhi politik dan ekonomi tetapi juga sejarah sosial dan kemasyarakatan. Perkara ini berlaku apabila British turut membawa masuk orang dari India termasuklah orang Islam untuk bekerja di sektor-sektor perladangan mahupun perkhidmatan di Myanmar. Menyentuh mengenai hal ini, Mahayudin Haji Yahaya dan Ahmad Jelani Halimi menyatakan bahawa:

Apabila British mula campur tangan dalam hal-ehwal Burma, orang Islam di Burma memainkan peranan yang penting dalam kegiatan ekonominya, malah terdapat ramai gabenor Islam yang mentadbirkan bandar dan pelabuhan utama di Tenasserim. Perahu 
layar kepunyaan raja Burma yang terakhir, Thibaw (1878-1885) sendiri dikendalikan oleh pelaut-pelaut Islam. ${ }^{20}$

Secara umumnya, kedudukan orang Islam di Myanmar dalam tempoh sebelum merdeka boleh disifatkan sebagai agak baik terutama dalam konteks hubungan dengan masyarakat tempatan beragama Buddha. Toleransi keagamaan yang tinggi membolehkan penganut pelbagai agama dapat hidup sebelah menyebelah. Ini bermakna, wujud kebebasan beragama meskipun agama Buddha masih tetap sebagai agama majoriti yang dianuti oleh orang Myanmar. Di Amarapura misalnya, sekitar 1850-an terdapat beberapa buah masjid yang terletak berhampiran dengan gereja dan biara Buddha. Orang Islam ini bermazhab syiah dan sunni. Bagi masyarakat bermazhab Syiah mereka akan menyambut perayaan 10 Muharam secara besar-besaran. Selain itu, sebahagian besar masyarakat Islam turut terserap dalam budaya tempatan. Wanita Islamnya jarang memakai tudung sebaliknya menggunakan pakaian sebagaimana wanita tempatan menggunakan bahasa Myanmar dan cara hidup Myanmar. ${ }^{21}$

Kehadiran British juga menyebabkan suasana masyarakat bersifat majmuk mula muncul di Myanmar. Kemasukan orang India terutama dari wilayah Madras, Bengal dan Uttar Pradesh ke Myanmar telah mempengaruhi komposisi penduduk. Orang Islam terutama dari Chittagong, Ramu dan Cox Bazaar turut membanjiri Myanmar terutama di wilayah Arakan. Faktor kemiskinan dan kemarau serta kesengsaraan di India diikuti dengan tarikan yang terdapat di Myanmar menyebabkan kemasukan ini berlaku. Dalam masa yang sama, penjajah yang sama di India dan Myanmar iaitu British telah menyebabkan proses penghijrahan dapat dilakukan secara mudah. Malahan pihak British dilihat turut mengalakkan proses hijrah masuk ini bagi menampung keperluan tenaga buruh. Pada 1931, jumlah penduduk Akyab ialah 38, 094 orang di mana majoritinya terdiri daripada orang India dan Rohingya. ${ }^{22}$

\section{Rohingya}

Dalam sejarah Islam di Asia Tenggara, salah satu aspek yang masih kabur mengenai masyarakat Rohingya. Kekurangan maklumat dan penelitian terhadap masyarakat ini telah menimbulkan masalah tersendiri apabila latar belakang mahupun identiti mereka masih tidak tidak jelas. Permasalahan yang dihadapi oleh masyarakat Rohingya turut sama menjadi isu yang diberikan perhatian oleh masyarakat Islam lain di rantau ini mahupun di peringkat antarabangsa. Dalam konteks yang lebih luas, masalah yang membelenggu masyarakat Rohingya menambahkan lagi permasalahan yang wujud dalam kalangan 
masyarakat Islam di rantau Asia Tenggara. Ini kerana, terdapat dua isu utama yang telah sekian lama mewarnai perkembangan sejarah orang Islam di rantau ini iaitu isu masyarakat Islam di selatan Thailand dan masyarakat Islam di selatan Filipina. Isu mengenai masyarakat Rohingya pula agak tenggelam timbul dan tidak sebagaimana isu di Pattani mahupun masyarakat Moro di Filipina. Jika diteliti secara mendalam, isu mengenai masyarakat Rohingya sebenarnya lebih teruk jika dibandingkan dengan masyarakat Islam di selatan Thai atau masyarakat Moro.

Sejarah kehadiran Rohingya ke Myanmar dilihat sangat panjang dan berliku serta mempunyai fasa-fasa yang tertentu. Secara keseluruhannya, orang Rohingya merupakan kelompok minoriti Islam di Myanmar yang berpegang kepada mazhab Sunni. Sebahagian besar orang Rohingya menetap di Rakhine (Arakan) terutamanya di sekitar Maungdaw, Buthidaung, Rathedaung, Sittwe (Akyab) dan Kyauktaw. Dalam menjelaskan mengenai orang Rohingya, Stephen L. Keck mengatakan bahawa mereka tinggal tidak jauh dari kawasan sempadan Bangladesh yang dipisahkan oleh Sungai Naaf dan bertumpu terutamanya di wilayah yang dikenali sebagai Mayu. Pada hari ini, wilayah tersebut dikenali sebagai Buthidaung dan Maungdaw. ${ }^{23}$ Aye Chan turut mengatakan bahawa orang Rohingya secara khusus merujuk kepada orang Islam yang menetap di Rakhine. ${ }^{24}$ Seorang pengkaji tempatan, Abu Talib Ahmad sewaktu menjelaskan mengenai masyarakat Rohingya menyebut:

\footnotetext{
Satu masalah besar dalam klasifikasi ini [etnologi] ialah kedudukan orang Islam yang dikenali dengan nama Rohingya. Ada antara mereka telah berhijrah ke Arakan sejak abad ke-16, malah ada pula yang datang lebih awal iaitu pada abad kesembilan sebagai peniaga dari Timur Tengah (walaupun ramai juga yang datang pada abad ke-20), dan menetap di sekitar Akyab-Chittagong. Orang Rohingya ini telah diasimilasikan dari segi budaya, bahasa tetapi masih mengekalkan agama Islam. Pada zaman penjajahan, mereka kerap kali disamakan dengan orang India, sementara selepas tahun 1948, ramai pula antara mereka yang dianggap sebagai bukan warganegara tempatan lalu tidak diberi sebarang keistimewaan yang lazimnya dikaitkan dengan rakyat peribumi Myanmar. ${ }^{25}$
}

Arakan atau lebih dikenali sebagai Rakhine hari ini sememangnya menjadi tumpuan utama orang Islam sejak sekurang-kurangnya abad ke-8 Masihi lagi. Kedudukannya yang terletak berhampiran dengan laut menjadi tempat persinggahan pedagang-pedagang Islam. Selain itu, ia juga terletak berhampiran Teluk Bengal dan menjadi satu lagi daya penarik penting kepada kehadiran dan penempatan pedagang 
Islam. Berdasarkan keadaan ini, maka tidak hairanlah sekiranya dilihat Rakhine menjadi antara wilayah di Myanmar yang mempunyai kepadatan penduduk Islam yang tinggi. Secara keseluruhannya, terdapat beberapa kelompok masyarakat Islam di Rakhine sebagaimana yang dijelaskan oleh Aye Chan:

\begin{abstract}
"The Muslim in the Arakan State can be divided into four different groups, namely the Chittagonian Bengalis in the Mayu Frontier; the descendents of the Muslim Community of Arakan in the Mrauk-U period (1430-1784), presently living in the Mrauk-U and Kyauktaw townships; the descendents of Muslim merceneries in Ramree Island known to the Arakanese as Kaman; and the Muslims from the Myedu area of Central Burma [Myanmar], left behind by the Burmese invaders in Sandoway District after the conquest of Arakan in 1784." 26
\end{abstract}

Berdasarkan keadaan ini, maka orang Rohingya itu sebenarnya hanya merujuk kepada keturunan imigran dari Chittagong yang menetap di Rakhine setelah wilayah tersebut jatuh ke tangan British di bawah Perjanjian Yandabo yang menamatkan perang Anglo-Burma antara 1824-1826. Golongan ini bertumpu di wilayah Mayu yang bersempadan dengan Bangladesh. Ketika zaman pemerintahan British, mereka dikenali sebagai 'Chittagonians' atau Bengali Muslim. ${ }^{27}$ Berdasarkan pandangan ini, masyarakat yang dikenali sebagai Rohingya itu sebenarnya merupakan fenomena abad ke-19 dan tidak mempunyai kaitan sama sekali dengan kehadiran masyarakat Islam yang lebih awal. Pandangan ini merupakan satu dari aliran pemikiran yang wujud dalam melihat isu Rohingya dan pada dasarnya keadaan ini menjelaskan bahawa orang Rohingya terdiri dalam kalangan imigran yang masuk ke Myanmar dan menetap di Rakhine terutama di daerah Mayu apabila dibawa oleh pihak British.

Walau bagaimanapun, pandangan ini ditolak oleh aliran yang menegaskan bahawa catatan sejarah menunjukkan bahawa orang Rohingya telahpun berada lama di Myanmar terutama di Rakhine sejak sebelum kehadiran British lagi. Aliran ini menegaskan bahawa orang Rohingya bukanlah hasil dari penjajahan British di Rakhine atau fenomena abad ke-19 sebagaimana dakwaan aliran pertama. Sebaliknya perkara ini perlu dikaitkan dengan perkembangan Islam sejak abad ke-8 masihi lagi. Secara lebih terperinci, aliran ini menegaskan bahawa orang Rohingya yang wujud di Myanmar hari ini merupakan gabungan satu perkembangan sejarah yang cukup panjang yang bermula sejak abad ke-8 masihi itu. Kemasukan orang Islam dari Benua Kecil India semasa zaman penjajahan British pada abad ke-19, hanya menyebabkan kedudukan orang Islam semakin kompleks kerana menggabungkan dua 
elemen iaitu orang Islam yang sedia ada di Rakhine bersama dengan kehadiran orang Islam yang dibawa oleh British.

Gabungan antara dua elemen inilah yang mewujudkan masyarakat Rohingya sebaik sahaja Myanmar mencapai kemerdekaan. Dalam masa yang sama, kemasukan imigran baru dari Bangladesh ke Rakhine juga tidak boleh ditolak sama sekali. Ini kerana kedudukannya yang hampir dengan negara tersebut serta adanya ikatan keagamaan telah menyebabkan kemasukan imigran dari Bangladesh. Mereka lebih dilihat sebagai imigran ekonomi yang keluar dari Bangladesh untuk mencari kehidupan yang lebih baik. Walau bagaimanapun, adalah sangat sukar untuk mengasingkan antara 'Rohingya' lama yang telah berada di Rakhine sejak Myanmar belum merdeka dengan 'Rohingya' baru yang masuk ke Rakhine selepas kemerdekaan. Ini kerana secara fizikal mereka mempunyai persamaan yang sangat ketara. Masalah untuk 'mengasingkan' mereka inilah yang turut menjadi cabaran kepada pihak berkuasa Myanmar, hingga akhirnya mereka melihat isu ini secara pukal yakni dengan mengelompokkan kesemua mereka sebagai Rohingya yang diletakkan sebagai orang asing.

Secara keseluruhannya, dari segi penampilan fizikal, orang Rohingya kerap kali disalah anggap sebagai warga yang berasal dari India mahupun Bangladesh kerana kulit mereka agak gelap jika dibandingkan dengan kalangan etnik Myanmar yang lain. Mereka menggunakan bahasa Rohingya dan Myanmar sebagai bahasa pertuturan utama. Nama Rohingya yang digunakan bagi merujuk masyarakat ini dikatakan berasal dari perkataan Rohang' iaitu nama lama bagi Arakan. ${ }^{28}$

Walau bagaimanapun, terdapat pandangan lain yang melihat istilah Rohingya berasal dari perkataan Arab iaitu 'Rahm' yang bermakna simpati atau dirahmati. ${ }^{29}$ Keadaan ini pastinya timbul sebagai satu usaha untuk 'melegitimasikan' kedudukan orang Islam di Rakhine itu sebagai satu perkembangan sejarah yang cukup panjang dan mempunyai kaitan langsung dengan kehadiran orang Arab ke Rakhine. Meskipun demikian, pandangan yang mengaitkan Rohingya dengan perkataan Arab bukan sahaja tidak mendapat sambutan, malah mendapat kritikan yang berterusan. Antaranya termasuklah dari Jahirudin Ahmed dan Nazir Ahmed iaitu bekas Presiden dan Setiausaha Persidangan Muslim Arakan. Antara lain mereka menegaskan:

\footnotetext{
"We met a few hundred of Muslims along the sea-shore near Akyab, known as 'Thambu Kya' Muslims meaning ship-wrecked Muslims... This Thambukya Muslim do not claim to be Ruhaingyas nor they know by others as such. Had Ruhaingyas been derived from Arabic word such 'Raham', these Thambukyas would have been the first group to be known as Ruhaingyas." 30
} 
Perdebatan mengenai hal ini dalam kalangan sejarawan terus berlaku. Usaha untuk mengenal pasti identiti Rohingya tidak hanya bersandarkan kepada satu persepsi kerana terdapat pandangan lain yang menyatakan bahawa Rohingya merupakan keturunan dari masyarakat Islam yang berasal dari Ruha atau Ruh yang terletak di Afghanisa:

"The Muslim conquers Bengal, including Bakhtiyar Khilji and the Muslim
deputed from Bengal to Arakan were originally the inhabitants of Ruah,
a district of Ghore in Afghanistan. These Muslims named Arakan as
Ruhang or Roshang. In the dialect prevailing in Chittagong and Arakan
'Ha' and 'Sha' are interchangeable... So Ruhang and Rosang are different
pronounciation of the same word. The Muslim themselves are known as
Ruhains meaning the offspring of Ruha." 31

Berdasarkan perkembangan sejarah, orang Rohingya dilihat merupakan kacukan daripada berbagai bangsa termasuklah Arab, Parsi, Afghanistan mahupun dari Bengal dan Chittagong. ${ }^{32}$ Seawal abad ke-8 Masihi, Arakan telah dikunjungi oleh pedagang-pedagang Arab yang bertindak menyebarkan Islam ke Arakan. Malah nama Arakan sendiri dikatakan diambil dari perkataan Arab iaitu 'Arkan' yang bermakna rukun-rukun. ${ }^{33}$ Walau bagaimanapun, kehadiran mereka di tahap awal ini dalam jumlah yang secara relatifnya tidak terlalu besar. Namun demikian, ia menjadi asas dalam melihat pertapakan Islam mahupun kewujudan masyarakat Rohingya di Arakan. Kehadiran Islam menjadi semakin ketara pada abad ke-15 apabila tentera-tentera upahan beragama Islam yang berasal dari Afghan, Parsi dan India mula datang ke Arakan. Malah mereka turut terbabit dalam konflik di Arakan, misalnya dalam perebutan tahta di Mrauk U (Kyaupku) yang merupakan ibu negeri Arakan ketika itu.

Selain itu, pada 1660-an golongan yang kemudiannya dikenali sebagai orang Islam 'Kaman' turut datang ke Arakan. Mereka merupakan pengikut Shah Shuja iaitu putera pemerintah kerajaan Mughal, Shah Jahan yang melarikan diri kerana pertelingkahan politik di Delhi. Selepas ini juga dikatakan lebih ramai orang Islam datang ke Arakan menyusul Shah Shuja dan mereka menetap di sekitar Mrauk U walaupun kemudiannya berpindah ke kawasan lain termasuklah Pulau Ramree atau Pulau Cheduba. ${ }^{34}$

Jumlah orang Islam dari Chittagong dan Bengal semakin besar masuk dan menetap di Arakan apabila Arakan dijadikan sebagai sebahagian wilayah pentadbiran British India bermula 1826. Mereka dijadikan kakitangan pentadbiran di kawasan-kawasan lain di Myanmar yang telah jatuh ke tangan British termasuklah kawasan Myanmar Hilir yang dibangunkan oleh British sebagai kawasan pengeluaran pasir 
yang paling penting di dunia diikuti wilayah Shan yang kaya dengan pelbagai jenis logam bernilai serta wilayah Toungoo dan Tenasserim yang menjadi sumber kayu balak kepada pihak British. ${ }^{35}$

Kesan penting dari kehadiran orang Islam ini adalah wujudnya perkahwinan campur dengan masyarakat tempatan dan hasil dari perkahwinan ini adalah masyarakat peranakan. Perkembangan yang telah berlaku sejak sekian lama ini telah menyebabkan persoalan identiti dan siapakah Rohingya menjadi semakin kompleks. Ini kerana terdapat beberapa kategori golongan ini. Pertama, golongan Rohingya yang telah lama menetap di Arakan, sejak sekurang-kurangnya abad ke-8 itu yang telahpun bercampur dengan masyarakat tempatan untuk puluhan generasi. Kedua, orang Arakan setempat yang memeluk agama Islam dan ketiga mereka yang datang dari wilayah Bengal dan Chittagong kesan dari penjajahan British ke atas Myanmar. Selain itu, terdapat juga golongan pendatang yang baru memasuki Myanmar dari Chittagong dan Bengal sejak penghujung abad ke-19 dan abad ke-20 yang lebih kepada pendatang ekonomi.

\section{Minoriti yang Terasing}

Antara aspek penting yang mendasari isu-isu mengenai masyarakat Islam Rohingya di Myanmar ini adalah mengenai status mereka. Ketika zaman pemerintahan British di Myanmar, orang Rohingya dikelompokkan dalam kategori Indo-Burman dan dalam kedudukan ini, mereka yang turut dirujuk sebagai Muslim Arakan telah diiktiraf sebagai keturunan dari Chittagong yang beragama Islam dan telah berkahwin dengan wanita berbangsa Arakan. Pada penghujung 1930an, jumlah mereka kira-kira dua perlima daripada jumlah keseluruhan penduduk Arakan. ${ }^{36}$

Berdasarkan kepada perbincangan yang telah dijelaskan di atas, maka persoalan mengenai status Rohingya merupakan satu perkara serius yang terus berlanjutan hingga ke hari ini. Ketika zaman penjajahan British, orang Rohingya diklasifikasikan sebagai Indo-Burman, ketika zaman merdeka, status mereka adalah bukan warganegara. Keadaan ini pastinya menimbulkan persoalan kerana orang Rohingya telahpun mendiami Arakan sejak ratusan tahun yang lalu, namun mereka tidak diakui sebagai warga Myanmar. Sejarah yang dipegang oleh orang Rohingya masih tidak cukup untuk membolehkan mereka diberi status pribumi yang sepatutnya dimiliki oleh orang Rohingya.

Dalam banyak keadaan, status orang Islam amnya dan Rohingya khasnya sebagai minoriti 'yang terasing' dalam kerangka kewujudan masyarakat Myanmar merupakan sumbangan penjajahan British di Myanmar. Adalah sangat ketara pemerintahan British di negara- 
negara yang dikuasainya mempunyai persepsi tersendiri terhadap orang Islam. Dalam menjelaskan hal ini, Stephen K. Keck misalnya mengatakan, "Colonial administrators in many parts of the Empire [British Empire] regarded Islam as a potential threat: the fear that Muslims might call for jihad against the British was a fear articulated in many imperial venues". ${ }^{37}$ Berasaskan keadaan ini, maka pemerintahan British di Myanmar telah mengasingkan orang Islam dalam kategorinya sendiri. Orang Islam di Myanmar termasuklah yang telah berada di Myanmar ratusan tahun sebelum kedatangan British sekalipun telah diberikan status 'other' oleh pihak British. Keadaan inilah yang terus kekal dalam kerangka pemikiran dan perjalanan sejarah Myanmar hingga sukar dihilangkan meskipun setelah Myanmar mencapai kemerdekaan. Penentuan status dilakukan berdasarkan kepada etnik dan agama. Ini bukanlah kriteria yang digunakan untuk meletakkan satu-satu kumpulan sebagai etnik Myanmar. Keadaan ini pastinya menjelaskan kedudukan orang Rohingya yang dilihat sebagai kelompok orang asing kerana agama yang dianutinya berbeza sama sekali dengan ciri-ciri 'tempatan' sekiranya dibandingkan dengan etnik lain seperti Kachin, Karen dan sebagainya:

"Minority status became based upon ethnicity (and at times location) and not religion. This would be the case with the creation of colonial heritage as well. Burma's Muslims simply did not fit into this picture. They were, in fact, on their way to becoming an 'invisible minority'." 38

Dalam mengupas perkara ini, timbul pertanyaan mengapa wujud permasalahan mengenai status Rohingya ini berlaku? Terdapat sekurang-kurangnya dua penjelasan, pertama, masyarakat Rohingya dianggap sebagai kumpulan marginal dalam kerangka kehidupan politik, ekonomi dan sosial orang Myanmar. Ini bermakna, masyarakat Rohingya akan terus terpinggir dari arus pembangunan sama ada dari aspek agama, budaya, politik, ekonomi, pentadbiran dan pendidikan. Perbezaan agama menjadi antara garis penentu dalam melihat status pribumi oleh kerana orang Rohingya menganut agama Islam berbanding kumpulan masyarakat lain yang beragama Buddha hingga menyebabkan kedudukan Rohingya sebagai bukan pribumi berterusan. Kedua, selain status pribumi orang Rohingya juga bukan warganegara. Mereka tidak dilihat sebagai warga Myanmar hingga menyebabkan status mereka terumbang-ambing. Mereka menjadi pelarian di negara sendiri meskipun telah menetap di Arakan sejak puluhan generasi. pelbagai rupa bentuk strategi dilakukan bagi menafikan status dan kedudukan orang Rohingya. Ini terjelma melalui kewujudan penempatan tentera di wilayah Arakan, menambah bilangan pegawai 
tinggi tentera berketurunan bukan Rohingya dan sebagainya. Malah, terdapat juga kes-kes kekerasan dan penindasan termasuklah merampas harta benda milik orang Rohingya, rumah, tanah dan sebagainya. Tanpa status warganegara, maka orang Rohingya sebenarnya seolah-olah menjadi penumpang di tanah milik mereka di negara mereka sendiri.

Konflik membabitkan Rohingya juga wujud kerana dasar-dasar Burmanisasi yang cuba dilakukan oleh kerajaan Ne Win. Dengan merujuk kepada tindakan kerajaan Thailand yang 'mensiamkan' orang Cina, kerajaan Ne Win juga berhasrat agar orang Rohingya turut menggunakan nama Myanmar serta meninggalkan budaya dan cara hidup mereka agar mereka boleh bercampur dengan masyarakat Myanmar yang lain. Walau bagaimanapun, kaedah paksaan yang digunakan oleh Ne Win tidak berjaya dan menyebabkan orang Rohingya menolak sebahagian dasar tersebut terutama dalam hal mengenai agama dan budaya. Ketika mereka tidak mempunyai masalah besar untuk menggunakan bahasa Myanmar, namun hal mengenai agama masih menjadi isu sensitif. Hal ini timbul kerana mereka bangga dengan pegangan agama dan budaya yang mereka amalkan dan tidak mudah bagi mereka untuk meninggalkannya. Pertentangan dua kebudayaan dan kepercayaan ini akhirnya meninggalkan kesan konflik. Ketika orang Rohingya dan Rakhine mempunyai ikatan dan pertalian dengan tamadun dan kebudayaan Islam, Myanmar pula merupakan "great culture of Buddhist learning and civilization for centuries". ${ }^{39}$

Perbezaan antara agama dilihat menjadi asas kepada konflik yang berlaku. Hal ini pastinya bertepatan dengan pandangan yang dilontarkan oleh Samuel P. Huntington yang menyebut mengenai konflik garis sesar. Huntington menjelaskan bahawa konflik garis sesar merupakan konflik yang membabitkan masyarakat antara negara atau kumpulan daripada tamadun yang berbeza:

Kadang-kadang konflik garis sesar merupakan perjuangan untuk menguasai penduduk. Yang sering kali berlaku ialah isu penguasaan wilayah. Matlamat bagi sekurang-kurangnya satu peserta adalah untuk menakluki wilayah dan membebaskan wilayah itu daripada orang lain dengan menghalau mereka keluar, membunuh mereka, atau melakukan kedua-duanya sekali, iaitu melalui 'penghapusan etnik'. Konflik seperti ini biasanya ganas dan kotor, dengan keduadua pihak melakukan pembunuhan beramai-ramai, keganasan, perkosaan dan penyeksaan...Perang ini merupakan konflik yang berpanjangan. Apabila konflik ini berlaku dalam sesebuah negara, ia secara puratanya berlanjutan enam kali lebih lama daripada perang antara negara... ${ }^{40}$ 
Isu mengenai perbezaan etnik serta status ini menjadi semakin ketara pada era 1920-an dan 1930-an apabila berlaku zaman kemelesetan dunia yang tempiasnya turut melanda Myanmar. Kedudukan Myanmar yang terpisah dari kerajaan British India sejak 1937 turut sedikit sebanyak mempengaruhi keadaan ini. Pada 1 April 1937, di bawah ketetapan Akta Kerajaan India 1935, pentadbiran Myanmar dipisahkan dari India dan membentuk pentadbiran berasingan di bawah kerajaan British Myanmar. Perubahan ini dilihat merupakan tahap penting dalam perkembangan sejarah Myanmar dan diterima baik oleh warga Myanmar. Dengan perubahan ini, Arakan diletakkan di bawah pentadbiran Rangoon (Yangdon) dan terus kekal sebagai sebahagian dari Myanmar ketika kemerdekaan 1948.

Pertelingkahan antara orang Rohingya dengan etnik lain di Arakan terutama Rakhine dapat dilihat berdasarkan beberapa tahap. Sebagaimana yang diperjelaskan di atas, perkara ini berlaku sekitar 1780-an kesan dari kehadiran orang Burman di Arakan. Selain itu, pertelingkahan turut berlaku pada 1870-an dan seterusnya pada era Perang Dunia Kedua. Ketegangan membabitkan kumpulankumpulan etnik telah berlaku kesan timbulnya perasaan tidak puas hati masyarakat etnik lain terhadap masyarakat Rohingya. Rasa tidak puas hati ini semakin bertambah dengan kemelesatan ekonomi hingga tekanan yang dirasakan oleh kumpulan etnik lain dilepaskan kepada Rohingya yang dianggap bukan orang Myanmar. Keadaan ini berulang pada 1920-an dan 1930-an apabila ekonomi mengalami kemelesetan teruk hingga penduduk di Delta Myanmar menjadikan orang Rohingya sebagai sasaran kemarahan mereka.

Pertelingkahan membabitkan Rohingya dengan etnik lain berlaku lagi pada era Perang Dunia Kedua. Pada 1942 kira-kira 100,000 orang Rohingya terkorban kesan dari pertelingkahan dengan orang Burman dan Rakhine. Ini secara langsung memaksa 80,000 orang Rohingya melarikan diri meninggalkan kampong halaman mereka. ${ }^{41}$ Sebanyak 294 perkampungan Rohingya dimusnahkan. ${ }^{42}$ Malah terdapat juga pandangan yang menegaskan bahawa kerajaan Myanmar turut bekerjasama dengan pihak Jepun pada 1942-1943 untuk mengusir kirakira 400,000 orang Rohingya. Kehadiran Jepun juga telah menyebabkan orang Rohingya melarikan diri ke Chittagong. Ketika ini juga, orang Rohingya didapati memberi sokongan kepada pihak British hingga perkara ini menjadi satu alasan untuk pihak Jepun turut terbabit menahan dan mengusir mereka:

"As the Japanese pushed North, they met up against stiffer and more organized resistence and were not only held, but forced to retreat, for they are, man to man, no match for the Mussalman Arakanese. The immediate 
result to us was that is separate the two peoples into two district areas of influences, and it is to those areas that we have to base our whole system of intelligence, and they likewise for the uses and tries to use the Maughs in the same way as we use the Mussulman, but fortunately not to the same effect. Added to the fact that the Mussulmans are more trustworthy and in my opinion more courageous." 43

Selepas PD 2, pihak British mula memikirkan untuk memberikan kemerdekaan kepada Myanmar. Namun demikian, permasalahan orang Rohingya yang melarikan diri ketika zaman penjajahan Jepun masih tidak selesai kerana hanya sebahagian sahaja yang berjaya kembali ke Myanmar sementara kira-kira 13,000 orang masih kekal di Bengal. ${ }^{44}$ Dalam situasi ini, wujud pula pemberontakan di Arakan serta beberapa wilayah di Myanmar hingga menyebabkan isu mengenai kemerdekaan terpaksa ditangguhkan sementara waktu. Di Arakan, kebangkitan berlaku membabitkan orang Rakhine dan Rohingya. Kedua-dua belah pihak mempunyai organisasi dan pertubuhan sendiri yang berusaha untuk mencapai matlamat mereka. Orang Rohingya berusaha untuk mendapatkan sebuah negara Islam yang merdeka sementara Rakhine pula mempunyai matlamat yang tersendiri dan keadaan ini telah memberi kesan kepada suasana politik di Arakan. Orang Rohingya telah membentuk gerakan-gerakan politik atas nama Mujahid bagi menentang kerajaan. Kebangkitan etnik ini telah secara langsung menjejaskan hubungan yang sedia rapuh antara orang Rohingya dengan Burman. ${ }^{45}$ Kebangkitan Mujahid ini, meskipun tidak merangkumi seluruh Myanmar, namun agak berpengaruh di Arakan. Gerakan ini dikatakan menerima simpati dari Pakistan Timur (Bangladesh), namun gerakan yang berlaku sejak 1948 ini dapat dikawal oleh pihak kerajaan. Pada bulan Oktober 1950, gerakan ini menjadi semakin lemah apabila pemimpin gerakan, Jaafar Hussain terkorban. ${ }^{46}$

Walau bagaimanapun, tidak wujud kesatuan dalam kalangan orang Rohingya kerana mereka didapati terpecah kepada beberapa kumpulan dan berpegang kepada fahaman yang berbeza-beza. Terdapat kumpulan yang agak ekstrim dan militan serta berjuang untuk kemerdekaan untuk masyarakat Rohingya seperti yang ditunjukkan oleh gerakan Mujahid ataupun Kesatuan Perpaduan Rohingya, Barisan Patriotik Rohingya, Tentera Pembebasan Rohingya, Parti Pembebasan Rakyat Arakan dan Harkat-e-Jihadul Islam. Selain itu terdapat juga kumpulan yang lebih moderat sifat perjuangannya seperti Barisan Rohingya Islam Arakan, Kesatuan Muslim Burma dan Organisasi Pembebasan Islam Burma. Dua pertubuhan terakhir bersifat lebih umum iaitu berjuang untuk semua orang Islam di Myanmar dan tidak hanya bertumpu kepada Rohingya sahaja. ${ }^{47}$ Liga Muslim Arakan Utara yang ditubuhkan pada 
bulan Julai 1946 pula berjuang untuk mengadakan penyatuan dengan Pakistan. ${ }^{48}$ Wujudnya kumpulan-kumpulan ini menunjukkan bahawa orang Rohingya sendiri mempunyai sikap dan pandangan yang terpecah-pecah dalam usaha mereka untuk mendapatkan hak mereka serta memastikan kebajikan, ekonomi, sosial dan politik mereka terjamin di Myanmar.

Kebangkitan-kebangkitan bersifat keras dan militan yang meletus pada 1948 berlangsung kesan dari kegagalan hubungan antara orang Rohingya dengan pemerintah di Yangon. Masalah-masalah utama yang cuba dibangkitkan oleh orang Rohingya bukan sahaja tidak dapat diselesaikan dengan baik, malah menempuh jalan buntu apabila Yangon enggan meneliti permalahan tersebut termasuklah isu mengenai peluang ekonomi dan pendidikan, jawatan dalam kerajaan, pembabitan dalam pasukan tentera malah adanya usaha untuk menghalang pergerakkan orang Rohingya terutama membabitkan wilayah Buthidaung, Maungdaw dan Rathedaung. Sekatan pergerakan ini menyebabkan kehidupan orang Rohingya menjadi sangat sukar. Kerana keadaan-keadaan inilah, kebangkitan Mujahid berlaku dan pada tahap awal ia mendapat kemenangan. Terdapat juga pandangan yang mengatakan gerakan ini menerima bantuan dari Pakistan. Jaafar Hussain yang menjadi pemimpin Mujahid mula dilihat sebagai musuh nombor satu kerajaan dan usaha untuk memastikan gerakan ini dapat dikalahkan atau menjadi lemah adalah dengan menghapuskan Jaafar Hussain. Jaafar Hussain mula menjadi buruan. Usaha kerajaan untuk melemahkan gerakan Mujahid bukan sahaja dilaksanakan secara terus iaitu memburu anggota kumpulan ini, malah turut mendapatkan sokongan oleh Rohingya yang moderat dan menyokong Yangon. Keadaan ini secara langsung mengecilkan sokongan orang Rohingya kepada Mujahid. Walau bagaimanapun, apa yang berlaku tidak tamat begitu sahaha sebaliknya saki baki kumpulan ini terus berjuang sehingga 1961 apabila mereka menyerah diri. Mereka telah diberikan sedikit wang, senaskah al-Quran dan diberikan tanah untuk bertani di sebuah kem tentera di Maungdaw. ${ }^{49}$

Penting untuk disebutkan bahawa ketika menjelang kemerdekaan, di bawah undang-undang kerakyatan Myanmar 1947, sekali lagi orang Rohingya menjadi sasaran. Berdasarkan undang-undang ini, anggota keluarga yang berada di Myanmar ketika era Perang Dunia Kedua, yang tidak melarikan diri berhak untuk mendapatkan kewarganegaraan penuh. Mereka yang melarikan diri tidak akan diiktiraf sebagai warganegara. Berdasarkan undang-undang ini juga, mana-mana warga Myanmar perlu menunjukkan bukti bahawa anggota keluarga mereka tinggal di Myanmar semasa peperangan dan bukti dalam bentuk 
dokumen ini merupakan antara elemen penting yang membolehkan seseorang itu untuk mendapatkan kewarganegaraan Myanmar:

"A Burma national is defined for the purpose of eligibility to vote and to stand as a candidate at the forthcoming election as a British subject of an Indian States who was born in Burma and resided not less than eight years in ten year immediately preceding either January $1^{\text {st }} 1942$ or January $1^{\text {st }}$ 1947." 50

Undang-undang ini memberi kelebihan kepada etnik Burman dan Rakhine serta lain-lain yang ada di Myanmar. Kumpulan yang terjejas ialah Rohingya yang melarikan diri dan terpaksa berlindung di negara lain. Sebahagian dari orang Rohingya yang mempunyai dokumen dan bukti mula kembali ke Myanmar sementara sebahagian besar pula menghadapi masalah kerana ketiadaan dokumen. Walau bagaimanapun, apabila mereka pulang ke kampung halaman mereka, didapati bahawa perubahan berlaku apabila harta benda mereka, rumah dan tanah telah menjadi milik orang lain. Keadaan ini secara langsung menjejaskan kehidupan mereka dan masalah ini terus menghantui orang Rohingya sebaik sahaja Myanmar mencapai kemerdekaan.

Berdasarkan perbincangan ini, maka jelaslah bahawa orang Rohingya lebih merupakan golongan peranakan iaitu kesan dari perkahwinan yang berlaku antara orang Islam yang berasal, terutamanya dari Bengal dan Chittagong dengan wanita tempatan di Arakan. Mereka telah berada di Arakan sejak sekurang-kurangnya abad ke-8 Masihi. Perkembangan sejarah turut membuktikan bahawa orang Rohingya merupakan penduduk asal Myanmar dan Islam yang menjadi agama anutan mereka menjadi asas penting dalam kehidupan mereka. Malah, Islam turut menjadi asas berkerajaan sebagaimana yang dibayangkan melalui kewujudan Dinasti Shah.

\section{Kesengsaraan Rohingya}

Sejak Burma (nama ketika itu) menceroboh Arakan pada 1784 Masehi, penduduk Muslim Arakan dijadikan sasaran oleh mereka untuk dibunuh dan dihapuskan secara besar-besaran. Motif mereka ialah mahu menukar Arakan menjadi satu wilayah Buddha yang berpengaruh di Myanmar. Berikutan pemisahan pentadbiran Myanmar daripada India dan pengenalan Peraturan Rumah atau juga dikenali sebagai Home Rule pada 1937, peluang untuk mereka menghapuskan umat Islam terbuka luas. ${ }^{51}$ Bagaimanapun, selepas junta tentera mula berkuasa pada 1962, senario politik di Myanmar berubah secara drastik. ${ }^{52}$ Dengan kuasa dan kekuatan ketenteraan yang ada, penindasan besar-besaran ke atas kaum Muslimin terus meningkat berlipat kali ganda. Selama hampir 
empat dekad sahaja, lebih kurang 1.5 juta Muslim Rohingya dipaksa keluar dari tanah air mereka manakala saki baki yang masih tinggal hanya menghitung hari dengan penuh ketakutan, khuatir nyawa sendiri melayang pada bila-bila masa di tangan tentera.

Keadaan semakin parah pada 1978 apabila melalui 'Pelan 20 tahun Pembasmian Rohingya (The 20-year Rohingya Extermination Plan), Majlis Negeri Arakan (Arakan State Council) di bawah kawalan langsung Majlis Negara Burma (State Council of Burma) melancarkan kod operasi yang dinamakan Naga Min (King Dragon Operation). Operasi ini secara keseluruhannya bertujuan untuk menangkap pendatang haram yang terdapat di Myanmar terutamanya dari China, Bangladesh, India dan Nepal. Pendatang haram ini masuk ke Myanmar untuk mendapatkan pekerjaan dan kemudiannya kekal di Myanmar tanpa sebarang dokumen. Pihak kerajaan merasakan wujudnya kemasukan pendatang haram yang tidak terkawal ke Myanmar terutamanya dari Bangladesh. Kemasukan yang berlaku telah menimbulkan masalah di Rakhinedan oleh pihak berkuasa kerana mereka merasakan tindakan keras wajar dilaksanakan. Berdasarkan pihak berkuasa, kira-kira 19, 457 orang Bangladesh telah memasuki Myanmar. ${ }^{53}$ Melalui operasi Naga Min pada 19 Mei 1978, regim pemerintahan Myanmar mengumumkan di Buthidung terdapat 198,431 orang telah disoal siasat. Tindakan undangundang yang dikenakan terhadap 35, 596 orang dan 6, 294 buah rumah telah dirampas. Selain itu, seramai 101, 048 orang telah melarikan diri dari Buthidung dan Maugdaw sebaik sahaja operasi dilancarkan bagi mengelakkan diri dari disoal siasat. ${ }^{54}$ Walau bagaimanapun, ia hanya sebahagian dari kisah operasi Naga Min.

Ini kerana, meskipun operasi Naga Min dilihat untuk menjejaki pendatang haram, namun adalah jelas, sasaran regim pemerintahan Myanmar ialah orang Rohingya yang pada pandangan kerajaan, mereka bukan orang Myanmar. Malah lebih memburukkan keadaan, orang Rohingya ini juga tidak mempunyai sebarang dokumen pengenalan diri hingga menyebabkan tindakan diambil terhadap mereka. Operasi ini dianggap sebagai operasi paling kejam yang memberi kesan besar kepada orang Rohingya.

Operasi ini bermula pada 6 Februari 1978 di sebuah perkampungan orang Islam terbesar di Arakan iaitu Sakkipara di daerah Akyab. ${ }^{55}$ Apabila orang Islam menyedari bahawa mereka menjadi sasaran, mereka telah bertindak balas dengan alasan untuk mempertahankan diri hingga menjadi satu alasan kepada pihak kerajaan untuk bertindak lebih keras ke atas orang Rohingya. Tindakan anti-kerajaan yang dilakukan oleh orang Rohingya secara mudah dapat dipatahkan dan keadaan ini secara langsung memberi kesan besar kepada orang Rohingya yang mula merasakan keselamatan mereka terancam. Dari 
sinilah berlakunya gerakan keluar dari Myanmar dalam jumlah yang besar. Destinasi utama mereka ialah Bangladesh yang hampir dengan Myanmar. ${ }^{56}$ Mereka menyeberangi Sungai Naaf untuk sampai ke Bangladesh dan sungai ini merupakan sebahagian jajaran sepanjang $285 \mathrm{~km}$ yang memisahkan kedua-dua negara.

Perkembangan yang berlaku ini menghantar satu gelombang kejutan yang besar kepada semua pihak serta mula menarik perhatian masyarakat antarabangsa. Berita mengenainya tersebar dalam waktu yang singkat ke seluruh kawasan penduduk Islam. Kisah-kisah sedih, tragik dan pilu dengan cepat tersebar diikuti dengan berita penangkapan, pembunuhan dan penyeksaan. Keadaan ini telah menimbulkan rasa trauma kepada masyarakat Islam di Arakan Utara. Dalam bulan Mac tahun sama, operasi ini telah mencecah ke Buthidaung dan Maungdaw. Beratus-ratus orang Islam, lelaki dan wanita dihumban ke dalam penjara dan ramai lagi diseksa serta dibunuh. Kaum wanita pula dirogol di pusat tahanan. Rogol menjadi satu senjata yang amat berkesan untuk mengusir kaum Rohingya ini daripada kampung halaman mereka. Tanpa pengawasan daripada badan-badan antarabangsa, tindakan menghalang perbuatan ini masih gagal dikekang sehingga mengakibatkan wanita berada dalam ketakutan dan menjadi mangsa yang berterusan tanpa ada kesudahan.

Ketakutan melihat kekejaman yang tidak berperikemanusiaan ini ditambah dengan kedudukan nyawa, harta, kehormatan, nasib masa depan tidak menentu, maka sebahagian besar Muslim Rohingya lari meninggalkan kediaman masing-masing dengan merentas sempadan Myanmar-Bangladesh. ${ }^{57}$ Tindakan menghapuskan orang Rohingya menjadi reda apabila masyarakat antarabangsa mula memberi perhatian kepada isu ini. Yangon terpaksa menerima semula pelarian Rohingya apabila masyarakat antarabanga memberi tekanan, namun syarat ketat dikenakan. Yangon hanya akan menerima semula pelarian yang mempunyai dokumen yang menunjukkan mereka ialah warga Myanmar. Keadaan ini sebenarnya menjadi penghalang kepada usaha orang Rohingya untuk kembali ke Myanmar kerana mereka sememangnya tidak mempunyai sebarang bentuk dokumen. Hanya sebahagian kecil yang kembali ke Myanmar sementara sebahagian besar pula kekal sebagai pelarian.

Sekali lagi pada 18 Julai 1991 kempen pembasmian etnik termasuk orang Rohingya dilancarkan dengan kod "Pyi Thaya" dan menyaksikan pembunuhan serta pemerkosaan kejam ke atas kaum Muslimin Rohingya. Operasi pihak tentera di bahagian utara Rakhine menjadikan orang Rohingya sebagai sasaran mereka dan ini dilaksanakan atas alasan keselamatan. Dalam operasi ini, pihak tentera dan polis yang majoritinya ialah orang Burman telah ditempatkan di kawasan yang 
majoritinya terdiri dari orang Rohingya. Menjelang Januari 1992, jumlah pasukan keselamatan ini mencecah antara 25,000 hingga 30,000 orang. ${ }^{58}$ Intimidasi telah dilakukan oleh pasukan keselamatan ini hingga menimbulkan ketegangan dan pergaduhan.

Operasi yang dilaksanakan oleh kerajaan pada 1991 itu sebenarnya merupakan sebahagian dari 'program jangka panjang' pihak kerajaan untuk menghapuskan orang Rohingya. Ini kerana sejak 1989, telah ada usaha untuk membolehkan sesebuah wilayah yang majoritinya orang Islam dipecahkan dengan meletakkan orang Burman yang beragama Buddha. Ini secara jelas dilakukan di sekitar Mayu. Atas alasan keselamatan, orang Burman telah 'diarahkan' untuk menetap di Mayu hingga secara perlahan-lahan mereka mendominasi wilayah tersebut. Mereka akan mengambil alih tanah-tanah dan harta milik orang Rohingya hingga kemudiannya menyebabkan ketegangan etnik berlaku. ${ }^{59}$ Dalam kes di Rakhine ini, orang Burman seolah-olah bebas melakukan sebarang tindakan ke atas orang Rohingya kerana mereka akan dilindungi oleh pasukan keselamatan namun jika sebaliknya, orang Rohingya akan ditangkap dan dipenjarakan. Turut berlaku adalah kemusnahan tempat tinggal mereka begitu juga masjid-masjid.

Keadaan ini sekali lagi memaksa Muslim Rohingya lari beramairamai meninggalkan kampung halaman dan mencari perlindungan di tempat lain termasuk Bangladesh yang paling hampir dengan lokasi mereka. Bagaimanapun, dengan wujud perjanjian Myanmar-Bangladesh kemudiannya, sebahagian mereka kembali semula ke kampung halaman, manakala sebahagian lagi kekal berada dalam ketakutan dalam buangan. Setakat tahun 1999 sahaja, dilaporkan tidak kurang daripada 20 operasi yang berskala besar telah dilancarkan terhadap Muslim Rohingya oleh pemerintah junta. Laporan juga menyebut bahawa Muslim (kebanyakannya pemuda) telah dibunuh manakala ribuan lagi ditangkap dan diseksa. Bagi Muslimah pula, mereka sentiasa menjadi mangsa rogol dan hidup dalam ketakutan. Masjid-masjid yang telah sekian lama wujud dirobohkan dan digantikan dengan pagoda serta tokong-tokong selebihnya penempatan baru untuk penduduk beragama Buddha. Lebih menyedihkan, semua tokong dan pagoda itu dibina dengan peluh dan keringat kaum Muslimin yang dipaksa bekerja keras dan diperah keringat secara habis-habisan untuk menyiapkannya. Pada masa sama, pemerintah junta mencipta satu keadaan kebuluran di kawasan tersebut dan memaksa Muslim Rohingya keluar daripada kawasan berkenaan manakala ada juga yang mati kebuluran. ${ }^{60}$

Pada tahun 2001, keganasan dicetuskan lagi di Arakan di mana ratusan masjid dirobohkan dan 10 Muslim serta dua orang penganut Buddha dilaporkan terbunuh. Rusuhan ini meletus antara lain kerana pemusahan patung gergasi Buddha dari Lembah Bamiyan, 
Afghanistan oleh Taliban pada waktu itu. ${ }^{61}$ Peristiwa pemusnahan itu dengan cepat tersebar manakala risalah-risalah juga banyak disiarkan memfitnah kaum Muslimin yang dilakukan oleh SPDC pimpinan pemerintah tertinggi junta tentera Myanmar, Than Shwe. ${ }^{62}$ SPDC sendiri sememangnya terkenal dengan gerakan anti Muslim yang sering dilancarkan oleh mereka apabila ulama dan guru-guru agama Muslim Rohingya sering menjadi mangsa kekejaman mereka selain pemuda dan wanita Muslim. Kebanyakan pemimpin Muslim Rohingya pada masa ini dipenjara di atas dakwaan palsu yang sengaja diada-adakan terutamanya yang berkaitan dengan kewarganegaraan. ${ }^{63}$

Secara ringkasnya, operasi-operasi utama pasukan ketenteraan Myanmar ke atas Muslimin Rohingya sejak tahun 1948 adalah seperti dalam jadual berikut:

Jadual 1: Operasi ke atas Rohingya

\begin{tabular}{|l|l|l|l|}
\hline & Nama Operasi & Pihak Terlibat & Tahun \\
\hline 1. & Military Operation & $5^{\text {th }}$ Burma Regiment & November 1948 \\
\hline 2. & Burma Territorial Force (BTF) & BTF & $1949-1950$ \\
\hline 3. & Military Operation & $\begin{array}{l}2^{\text {nd }} \text { Emergency Chin } \\
\text { Regiment }\end{array}$ & Mac 1951-1952 \\
\hline 4. & Mayu Operation & Junta Tentera & Okt 1952-1953 \\
\hline 5. & Mone-thone Operation & Junta Tentera & Oktober 1954 \\
\hline 6. & Combined Operation & $\begin{array}{l}\text { Imigresen dan } \\
\text { Tentera }\end{array}$ & Januari 1955 \\
\hline 7. & Union Military Police (UMP) & UMP & $1955-1958$ \\
\hline 8. & Captain Htin Kyaw Operation & Junta Tentera & 1959 \\
\hline 9. & Shwe Kyi Operation & Junta Tentera & Oktober 1966 \\
\hline 10. & Kyi Gan Operation & Junta Tentera & Okt-Dis 1966 \\
\hline 11. & Ngazinka Operation & Junta Tentera & $1967-1969$ \\
\hline 12. & Myat Mon Operation & Junta Tentera & Feb 1969-1971 \\
\hline 13. & Major Aung Than Operation & Junta Tentera & 1973 \\
\hline 14. & Sabe Operation & Junta Tentera & $1974-1978$ \\
\hline 15. & $\begin{array}{l}\text { Naga Min (King Drag on) } \\
\text { Operation }\end{array}$ & Junta Tentera & Feb 1978-1979 \\
\hline 16. & Shwe Hintha Operation & Junta Tentera & Ogos 1978-1980 \\
\hline 17. & Galone Operation & Junta Tentera & 1979 \\
\hline 18. & Pyi Thaya Operation & Junta Tentera & Julai1991-1992 \\
\hline 19. & Na-Sa-Ka Operation & $\begin{array}{l}\text { Tentera dan agensi } \\
\text { dalam kuatkuasa } \\
\text { lain }\end{array}$ & $\begin{array}{l}\text { Sejak 1992 dan } \\
\text { belum tamat }\end{array}$ \\
\hline & & & \\
\hline
\end{tabular}

Sumber: Laman web Amnesty International dan Human Right Watch. Untuk Amnesty International akses, http://www.amnesty.org/library. Bagi Human Right Watch sila lihat, http://www.hrw.org/library. 
Penting untuk ditulis di sini bahawa ada dua daripada hampir 20 operasi itu yang besar dan benar-benar memberi kesan kepada Rohingya. Bukan bermakna operasi-operasi lain tidak menjejaskan Rohingya, cumanya dua operasi ini mengakibatkan pembanjiran beramai-ramai warga ini ke negara ketiga, paling ramai ke Bangladesh, yang terletak paling hampir dengan Arakan. Dua operasi yang disebutkan ialah satunya, Operasi Naga Min yang dilancarkan pada Februari 1978, yang sememangnya disasarkan kepada komuniti Rohingya. ${ }^{64}$ Operasi ini dikatakan menjadi punca kebanjiran dalam jumlah yang besar Rohingya ke Bangladesh sehingga pada satu peringkat ia menimbulkan rasa kurang selesa di dalam hubungan dua negara yang berjiran sejak sekian lama ini.

Sementara itu, satu lagi operasi ialah Operasi Phi Thaya. Ia bertujuan menyingkirkan saki baki kaum Rojingya yang tidak dapat diusir susulan operasi-operasi sebelum ini yang berskala besar seperti Naga Min. Dalam operasi ini, tentera yang ditugaskan akan memeriksa jika orang Rohingya memiliki kad pengenalan sementara berwarna putih atau sebaliknya. Kebanyakan mereka tidak mempunyai sebarang dokumen. Akibatnya, golongan yang tiada dokumen, kad pengenalan atau memberikan sebarang bukti sepertimana dikehendaki tentera, akan ditahan, diseksa dan menerima penderaan cukup teruk. ${ }^{65}$ Tujuan operasi ini sendiri ialah memeriksa kemasukan haram ke Myanmar oleh mana-mana penduduk daripada Bangladesh, di mana kerajaan mendakwa mereka ini pendatang haram yang mendiami di sempadan Arakan. Di sini, jelas sekali, Rohingya menjadi sasaran mereka apabila kerajaan sendiri sebelum ini maklum bahawa Rohingya melarikan diri ke Bangladesh untuk berlindung daripada operasi yang dilancarkan.

Menjelang lewat 1991 Myanmar mendapat hampir AS\$500 juta hasil kontrak pengeluaran bersama dengan syarikat minyak asing. ${ }^{66}$ Begitu juga menjelang Jun 1992, laporan menyebut bahawa terdapat 57 kes pelaburan asing dalam sektor petroleum dan beberapa sektor penting lain dengan purata pendapatan berjumlah AS $\$ 831,560$ juta. ${ }^{67}$ Hasil daripada pelaburan asing ini membolehkan junta tentera mengukuhkan keupayaan ketenteraannya. Matlamat ini, tidak lain dan tidak bukan untuk menghapuskan pemberontak dan penentangpenentang kerajaan tentera begitu juga pemberontak etnik.

Pada penghujung 1988, kekuatan tentera Myanmar ialah 185,000 tentera. Menjelang 1992, jumlahnya berganda menjadi 286,000 iaitu penambahan sebanyak 50 peratus. ${ }^{68}$ Sekiranya sebelum tahun 1988, sempadan Myanmar dengan Bangladesh dan India diawasi oleh lima batalion infantri biasa. Tetapi, awal 1990-an bertambah menjadi 32 batalion bagi mengawasi di sempadan yang sama. ${ }^{69}$ Dapat difahami, perluasan saiz dan kekuatan ketenteraan Myanmar ada hubungkait 
atau berlaku serentak dengan pemilikan senjata dan bahan letupan dalam jumlah yang besar. Bermakna, sekiranya saiznya bertambah besar, senjata dan letupan juga akan menjadi bertambah banyak dan permintaannya tinggi. Memandangkan jalinan yang baik di antara Myanmar dan China difahami bahawa Myanmar secara terus-terusan menerima meriam dan bedilan dari negara komunis itu sejak 1990. China pula merupakan negara pembekal utama senjata kepada Myanmar dengan mendapat kontrak menjual kepada Yangoon senjata, bahan letupan dan peralatan ketenteraan lain, kesemuanya dianggarkan berjumlah AS $\$ 1.2$ bilion. $^{70}$ Dengan kecanggihan dan kelengkapan ketenteraan sebegitu, junta tentera dengan mudah boleh menghapuskan sesiapa sahaja yang dimahukan.

Misi penghapusannya tidak menemui jalan sukar atau berdepan kerumitan apabila lawannya tidak kira Rohingya atau pemberontak dan penentang junta hanya memiliki senjata yang bukan moden atau setanding dengan mereka. Mudah kata, kekuatan tentera Myanmar ini digunakan sepenuhnya untuk mengekang atau menyelesaikan masalah etnik dan politik di negara berkenaan.

\section{Rantaian Kesengsaraan Masyarakat Rohingya}

Masyarakat Rohingya ini bukan sahaja diburu dan ditindas menerusi operasi kenteraan dan undang-undang dalam usaha kerajaan di negara itu mahu menghapuskan minoriti ini. Bentuk-bentuk kekejaman fizikal dan kerohanian turut dilancarkan secara terancang bagi membolehkan golongan ini tidak berkembang atau memastikan bilangan Rohingya tidak bertambah. Dalam satu laporan kepada UNHCR yang dibacakan oleh Chris Lewa, Penyelaras International Religious Freedom pada 2007, masalah-masalah yang dihadapi minoriti Rohingya di Myanmar diperincikan. Kenyataan itu adalah berdasarkan pemerhatiannya dan kerja lapangan beliau di Arakan selama tujuh tahun. Di dalam laporan ini, Lewa ada menyebut bahawa Rohingya, dianggarkan berjumlah 800,000 orang mendiami Arakan State (Rakhine) yang bersempadan dengan Bangladesh berdepan dengan kehidupan yang sangat sukar. Mereka tidak dibenarkan keluar dari tiga bandar di Arakan tiada akses kepada pekerjaan, kesihatan dan pendidikan.

Kebuluran juga serius dalam kalangan warga Rohingya malahan mereka tidak dibenarkan berkhidmat sebagai kakitangan awam. Dari segi sosial, mereka perlu dapatkan kebenaran untuk berkahwin, dibiarkan hidup merempat dalam keadaan serba serbi daif tanpa dirangsang sebarang pembangunan. Paling serius, hak mereka untuk mengamalkan agama juga dicabuli sejak beberapa tahun lalu dengan pelbagai cara. ${ }^{71}$ Ternyata sekali mereka didiskriminasi daripada 
pelbagai penjuru-ekonomi, sosial dan politik. Semua ini berpunca daripada masalah utama iaitu, hak mereka dinafikan. Mereka ialah stateless maka sebarang penindasan, penafian, kezaliman dan pelbagai nama pendekatan yang negatif lain lebih mudah dilakukan ke atas Rohingya. Berkaitan dengan hambatan untuk menunaikan amalan keagamaan ini dapat dilihat daripada dari beberapa sudut termasuklah penutupan secara paksa masjid dan madrasah, halangan dalam upacara keagamaan dan larangan pembinaan masjid baru serta sekatan dalam membaik pulih masjid lama dan rosak. Selain itu, masyarakat Rohingya turut mengalami hambatan-hambatan berbentuk penangkapan tanpa sebab, pendidikan, buruh paksa, keizinan perkahwinan dan masalah kanak-kanak. Salah satu hambatan penting yang terpaksa dilalui oleh masyarakat Rohingya adalah dalam aspek keagamaan. Ini termasuklah penutupan secara paksa masjid dan madrasah. Pada Julai dan Ogos 2006, pihak berkuasa kerajaan junta mengarahkan supaya sejumlah besar masjid dan madrasah di seluruh Arakan ditutup. ${ }^{72}$

Apabila terdapat sesetengah penduduk tempatan yang enggan berbuat demikian kerana takutkan pembalasan Allah s.w.t , NaSaKa, sendiri bertindak meranapkan institusi terbabit. Dilaporkan, salah sebuah daripada lapan masjid ini kemudiannya dibina semula dengan material asal selepas jawatankuasa masjid melancarkan kempen dan petisyen untuk tujuan berkenaan. Jawatankuasa juga dikatakan memberi sogokan dalam jumlah yang besar kepada pihak berkuasa. Sementara itu, 17 lagi institusi keagamaan terselamat daripada dimusnahkan kecuali masjid besar Goat Pi. Sehingga hari ini, dua daripada masjid, satu di Krin Tha Mar dan satu lagi di Ba Da Gar masih ditutup. Di Bandar Rathhedaung (Rathedaung Township) dan Maungdaw Selatan, pihak berkuasa turut mengunci beberapa buah masjid dan madrasah pada Februari dan Mac 2007. ${ }^{73}$

Masyarakat Rohingya juga dilarang dari meraikan sebarang bentuk perayaan keagamaan. Pada 2004, penduduk Islam Rohingya dipaksa untuk merayakan perayaan bukan agama Islam. Ini disahkan oleh laporan Jabatan Kebebasan Beragama Amerika Syarikat. Dalam hal ini, ada laporan pada 8 November 2005 menyebut bahawa terdapat kempen daripada kerajaan junta untuk memaksa etnik minoriti Islam ini memeluk agama lain. ${ }^{74}$ Begitu juga Rohingya ini berdepan kesukaran untuk mengumpulkan jemaah bagi menunaikan solat Jumaat pada setiap minggu. Ini disebabkan oleh kebanyakan imam dan guru agama diberkas selepas mereka dikenal pasti mengadakan kelas agama dan menunaikan sembahyang berjemaah. Matlamat mereka, mahu menyisihkan umat Islam ini sekali gus menjadikan Rohingya bodoh dan buta huruf. Semasa perayaan Aidil Adha, tanpa terkecuali masyarakat Islam Rohingya perlu mendapatkan kebenaran untuk menyembelih 
lembu atau ternakan lain yang boleh dijadikan korban mengikut syariat Islam. Malahan, penganut Islam perlu menyerahkan daging korban itu kepda NaSaKa walaupun agama menuntut ia patut diagih-agihkan kepada golongan miskin, anak yatim dan sebagainya. ${ }^{75}$

Pengurusan tanah perkuburan juga tidak terlepas daripada mendepani masalah di Arakan. Mayat penganut agama lain disemadikan di tanah perkuburan Islam dan kaum Rohingya dipaksa membayar harga yang tinggi kepada para pegawai tentera sebelum mahu membuat segala urusan pengkebumian. Laporan oleh Amnesty International pada Mei 2004 menyebut, sejumlah 40 buah masjid dan komuniti Islam di Arakan diluluskan pada tahun 2000 untuk dimusnahkan. Tapak tempat beribadat dan persemadian ini kemudiannya didirikan dengan pagoda, kuil atau bangunan-bangunan kerajaan lain yang melambangkan agama Buddha. Tidak cukup dengan itu, untuk memastikan identiti Islam lenyap dari bumi Arakan, setiap pelosok tanah yang tidak didiami kaum Islam Rohingya akan dibina tempat beribadat agama lain atau bangunan tentera. Kaum Rohingya yang tidak dibunuh dipaksa oleh pegawai kerajaan untuk menyumbang wang ringgit atau menjadi buruh paksa bagi projek yang dibiayai kerajaan demi menghapuskan identiti Islam. ${ }^{76}$

Selain itu, masyarakat Rohingya juga terpaksa berhadapan dengan penangkapan tanpa sebab yang jelas oleh pihak berkuasa Myanmar. Sekurang-kurangnya 10 orang, termasuk dua ulama di Buthidaung dan empat orang di Maungdaw dipenjara hanya kerana mengubahsuai sebuah masjid tanpa mendapat kebenaran rasmi. Mereka didakwa di bawah Seksyen 5 (j), Akta Peruntukan Darurat dan dijatuhi penjara satu hingga dua tahun. Peruntukan itu antara lain menyebut mereka, "menjejaskan moral dan amalan awam atau sekumpulan orang dengan matlamat untuk cuba mempelekehkan Kesatuan (di sini bermakna rejim tentera yang memerintah) atau keluhuran undang-undang." 77

Di sebalik hambatan bersifat keagamaan sebagaimana yang dijelaskan di atas, masyarakat Rohingya juga berhadapan dengan hambatan lain yang datang dalam berbagai bentuk seperti pendidikan. Citizenship Act of Burma 1982 atau Undang-undang Kerakyatan Burma 1982 menafikan hak kaum Islam Rohingya untuk menimba ilmu. Pihak kerajaan junta tentera hanya membenarkan pelajaran sekolah menengah kepada rakyat Myanmar manakala Rohingya yang dirampas hak kewarganegaraan diharamkan daripada melanjutkan pelajaran. Walaupun anak-anak Rohingya yang lulus ujian kemasukan ke pengajian tinggi, mereka tidak dapat melanjutkan pelajaran ke pusat pengajian tinggi yang kebanyakannya terletak di Yangon. Ini disebabkan mereka dilarang keluar dari Arakan. Pelajar Rohingya juga dilarang ke Akyab (kini Sittwe), ibu negeri Arakan bagi menyambung pelajaran ke Universiti Sittwe. Akibatnya, beribu-ribu pelajar Rohingya tidak dapat 
melanjutkan pelajaran dan masa depan mereka diselubungi kegelapan. Begitu juga, orang Islam di seluruh Myanmar termasuk kaum Islam Rohingya dilarang membawa masuk sebarang bahan bacaan ilmiah Islam. Ia bertujuan untuk mengelakkan kaum Islam Rohingya daripada mendalami Islam.

Sementara itu, propaganda anti-Islam disebarkan melalui media tempatan yang dikuasai penuh oleh tentera. Buku-buku serta ceramah yang dirakam menghina Islam disebarkan secara meluas dan dijual dengan begitu terbuka. Kebenaran untuk berkahwin juga disekat dan sejak tahun 1988, hanya tiga perkahwinan dibenarkan dalam setahun. ${ }^{78}$ Pasangan Rohingya perlu mengemukakan permohonan jika mahu mendirikan rumah tangga. ${ }^{79}$ Kerajaan junta hanya meluluskan perkahwinan itu sekiranya syarat-syarat dipenuhi dan membayar yuran pendaftaran. Sekiraya tidak mendaftar atau membayar yuran perdaftaran perkahwinan, mereka akan ditangkap atau dipenjarakan. Kecuali Imam dan pemimpin agama, semua lelaki Muslim perlu mencukur jambang mereka sebelum dibenarkan berkahwin. Mereka semua perlu menandatangani perjanjian atau ikrar yang menyatakan mereka tidak akan memiliki anak melebihi dua orang. Peraturanperaturan ini baru diperkenalkan sejak Oktober 2005..$^{80}$

Sementara itu, ada pendapat yang menyatakan bahawa syarat sebelum berkahwin itu mudah dipenuhi tetapi setelah berdaftar, kaum wanita yang ingin berkahwin dimestikan menyertai latihan anjuran kerajaan di kem dan pusat latihan. Mereka terpaksa berpisah dengan keluarga selama beberapa hari. Ketika inilah, gadis-gadis dirogol sebelum dibenarkan pulang ke pangkuan keluarga.$^{81}$ Dalam pada itu, yuran pendaftaran begitu menyeksakan buat golongan miskin jika mereka mahu berkahwin. Secara keseluruhannya, pasangan Rohingya yang mahu berkahwin perlu membayar 50,000 hingga 300,000 kyat. ${ }^{82}$ Kebiasaannya, bakal pengantin lelaki dan wanita masing-masing perlu membayar jumlah yang sama. Ada yang terjerumus dalam beban hutang untuk melangsaikan wang pendaftaran perkahwinan, tetapi kebanyakannya gagal membayar balik lalu lari ke Bangladesh.

Bermula 2003, pihak berkuasa mula menuntut sejumlah wang yang besar sebagai cukai sebelum meluluskan mana-mana permohonan Rohingya untuk berkahwin. Dalam banyak kes, bukan sahaja kerajaan membataskan jumlah permohonan perkahwinan tetapi juga perlu menunggu lama untuk mendapat permohonan perkahwinan itu, walaupun telah membayar sejumlah besar wang bagi tujuan berkenaan. Malah, lebih buruk mereka terpaksa ke kem NaSaKa beberapa kali untuk mendapatkan kebenaran. Ini juga memerlukan wang belanja yang banyak dan terbuang begitu sahaja demi mendapatkan kebenaran perkahwinan. ${ }^{83}$ 


\section{Kesimpulan}

Masyarakat Rohingya merupakan antara masyarakat yang paling teruk menerima tekanan dan penindasan dari pihak pemerintah. Sejarah membuktikan bahawa kesengsaraan Rohingya telah berlaku sejak Mynamar belum mencapai kemerdekaan dan semakin teruk setelah pihak tentera mengambil alih pemerintahan. Secara umum, terdapat tiga asas berlakunya permasalahan ini. Pertama, wujudnya pertembungan peradaban membabitkan Islam dan Buddha hingga ia menjadi asas untuk menekan dan menindas golongan yang tidak sehaluan dengan dasar pemerintahan yang menekankan Buddhism. Burmanisasi yang telah dilaksanakan sejak 1960-an dikaitkan secara langsung dengan penerapan Buddhism serta budaya Burman yang merupakan golongan majority. Dalam keadaan ini, golongan yang sukar 'beradaptasi' mahupun menerima 'dasar kerajaan' ini akan dianggap sebagai 'tidak setia' malah 'bukan warganegara' dengan menafikan segala bukti-bukti sejarah yang sedia ada. Kedua, kewujudan orang Islam amnya dan Rohingya khasnya dilihat sebagai satu bentuk ancaman, bukan sahaja kepada idea Burmanisasi tersebut, malah kepada kedudukan agama Buddha dan negara Myanmar sendiri. Kedudukan orang Rohingya di Rakhine sering sahaja dilihat sebagai satu ancaman kepada ekonomi, sosial dan politik di Rakhine.

Keadaan ini menyebabkan satu usaha untuk menyeimbangkan penduduk dilakukan sejak 1960-an lagi dengan membawa masuk penduduk beragama Buddha untuk tinggal di Rakhine mahupun dengan meletakkan pasukan keselamatan yang besar jumlahnya di Rakhine dengan alasan keselamatan. Ketiga, ketidakupayaan pihak pemerintah untuk menerima hakikat bahawa Myanmar merupakan sebuah negara majmuk yang mengandungi berbagai etnik dan agama. Kegagalan memahami perjalanan sejarah Myanmar yang menyebabkan berlakunya interaksi antara berbagai bangsa sejak abad-abad awal menyebabkan satu keinginan untuk mendominasi negara oleh golongan majority menjadi sangat kuat. Dalam keadaan ini, tekanan majoriti yang agak ekstrim menjadi asas dalam pertelingkahan etnik membabitkan golongan minoriti termasuklah orang Rohingya.

\section{Nota}

Abu Talib Ahmad, Sejarah Myanmar, Kuala Lumpur: Dewan Bahasa dan Pustaka, 2000, hlm. 2-4.

2 Burma Handbook, New Delhi: Government of India Press, 1943, hlm. 10.

Ibid., hlm. 4.

Ibid., hlm. 13.

Abu Talib Ahmad, Sejarah Myanmar, hlm. 7.

Burma Handbook, hlm. 11. 
Ibid., hlm. 16.

Lihat Abu Talib Ahmad, Sejarah Tanah Besar Asia Tenggara, Kuala Lumpur: Dewan Bahasa dan Pustaka, 1991, hlm. 216-217.

T. W. Arnold, Sejarah Da'wah Islam (tra.), Jakarta: Widjaya, 1979, hlm. 222. Mahayudin Hj Yahaya dan Ahmad Jelani Halimi, Sejarah Islam, Kuala Lumpur: Fajar Bakti, 1993, hlm. 564.

Andre Wink, Al-Hind. The Making of the Indo-Islamic World, Vol. 1, Leiden: E. J. Brill, 1991, hlm. 260.

Ibid., hlm. 274.

Mahayudin haji Yahaya dan Ahmad Jelani Halimi, Sejarah Islam, hlm. 565. Abu Talib Ahmad, Sejarah Myanmar, hlm. 91.

Mahayudin haji Yahaya dan Ahmad Jelani Halimi, Sejarah Islam, hlm. 565 Abu Talib Ahmad, Sejarah Myanmar, hlm. 91.

Ibid., hlm. 43-44.

Mahayudin haji Yahaya dan Ahmad Jelani Halimi, Sejarah Islam, hlm. 566. Abu Talib Ahmad, Sejarah Myanmar, hlm. 62.

Mahayudin haji Yahaya dan Ahmad Jelani Halimi, Sejarah Islam, hlm. 566. Abu Talib Ahmad, Sejarah Myanmar, hlm. 153.

Ibid., hlm. 266.

Stephen L. Keck, 'The Making of an Invisible Minority; Muslims in Colonial Burma', http:/ / khmerstudies.org., hlm. 230. Diakses pada 2 April 2012. Aye Chan, 'The Development of a Muslim Enclave in Arakan (Rakhine) State of Burma (Myanmar)', SOAS Bulletin of Burma Research, Vol. 3, No 2, 2005, hlm. 396.

Abu Talib Ahmad, Sejarah Myanmar, Kuala Lumpur: Dewan Bahasa dan Pustaka, 2000, hlm. 8.

Aye Chan, 'The Development of a Muslim Enclave in Arakan (Rakhine) State of Burma (Myanmar)", hlm. 397.

Ibid.

Bernard Lewis (et.al.), The New Encyclopedia of Islam, Leiden: E. J. Brill, 1986, hlm. 96.

Mohammed Ali Chowdhury, "The Advent of Islam in Arakan and the Ruhaigyas (Rohingyas)" Pakistan Historical Society. 1(1), 2004, hlm. 54-56. Mohammed Ali Chawdhury, "Shah Shuja's Flight to Arakan and its Consequence", Pakistan Historical Society. 3(2), 2005, hlm. 54-56. Ibid.

Mosye Yegar, The Muslim of Burma. A Study of a Minority Group, Wiesbaden: Otto Harrassowitz, 1972, hlm. 15-18.

J. A. Berlie, The Burmanization of Myanmar's Muslim, hlm. 62-64. Abu Talib Ahmad, "Rohingya dan Konflik Etnik di Arakan (Rakhine)", dalam Abdullah Zakaria Ghazali dan Zulkanaian Abdul Rahman (eds.). Konflik Dunia Abad ke-20. Kuala Lumpur: Dewan Bahasa dan Pustaka, 2008, hlm. 103.

Abu Talib Ahmad, Sejarah Myanmar, hlm. 97-115.

Abu Talib Ahmad. (2008) "Rohingya dan Konflik Etnik di Arakan (Rakhine)", hlm. 103. 
Stephen L. Keck. 'The Making of an Invisible Minority: Muslims in Colonial Burma", hlm. 223.

Ibid., hlm. 224.

Ganganath Jha, Ethnic Politics in Souteast Asia and Quest for Identity, hlm. 129.

Samuel P. Huntington, Pertembungan Tamadun dan Pembentukan Semula Orde Dunia (terj.), Kuala Lumpur: Dewan Bahasa dan Pustaka, 2008, hlm. 380.

Genocide in Burma Against Muslim Arakan. (1978). Arakan: Rohingya Patriotic Front (RPF), hlm. 2-4.

Mohammed Yunus. (2001). A History of Arakan, Past and Present. Bangladesh, hlm. 158-159.

Anthony Irwin. (1949). Burmese Outpost. London: Collins, hlm. 23.

Abu Talib Ahmad, Sejarah Myanmar, Kuala Lumpur: Dewan Bahasa dan Pustaka, 2000, hlm. 399.

Ibid., hlm. 323.

Ibid., hlm. 392.

Ibid., hlm. 399.

Ibid.

Ibid., hlm. 400.

J. Silverstein. (1979). 'Burma'. Roger M. Smith. (ed.). Southeast Asia Documents of Political Development and Change. Ithaca: Cornell University, hlm. 91.

Abu Talib Ahmad, Sejarah Myanmar, hlm. 199-309.

Josef Silverstein, The Political Legacy of Aung San (penyunting), New York: Cornell University Press, 1993, hlm. 75-90.

Ganganath Jha, Ethnic Politics in Southeast Asia, hlm. 124.

Ibid., hlm. 125.

Operasi Naga Min atau King Dragon banyak disebut dalam buku, artikel dan jurnal mengenai minoriti khasnya yang merujuk kepada Rohingya di Myanmar. Sebagai contoh, lihat Arthur P Phayre, History of Burma, London: Susil Gupta, 1967, hlm. 179. Lihat juga buku G.E Harvey, History of Burma, London: Frank Cass, 1967, hlm. 4-80. Untuk rujukan lanjut lihat juga artikel Nurul Islam, The Rohingya Muslim of Arakan: Their Past and Present Political Problems, Bangladesh, April 2006. Terdapat juga kertas kerja yang menyebut mengenai operasi ini antaranya berjudul Genocide in Burma Against the Muslim of Arakan oleh Patriotic Front (RPF) pada 11 April 2005 di Geneva.

Abu Talib Ahmad, Sejarah Myanmar, hlm. 402.

Bangladesh District Gazetteers, Delhi: Gian Publishing House, 1987, hlm. 63, untuk maklumat lanjut, lihat http://www.rohingya.org/not_settler. htm.

Abu Talib Ahmad, Sejarah Myanmar, hlm. 402.

Ibid., hlm. 403.

Bangladesh District Gazetteers, Delhi: Gian Publishing House, 1987, hlm. 63, untuk akses lanjut lihat http:// www.rohingya.org/not_settler.htm. 
61 Lihat "Giant Buddha Statues "blown up", BBC News, Mac, 2001 dan boleh diakses di alamat: http:/ / news.bbc.co.uk/hi/english/world_asia/ newsid_1214000/1214384.stm.

62 Zinab Begum, The Plight of the Rohingya People of Arakan State of Myanmar memperincikan bagaimana perkara ini berlaku. Menurutnya, pada 4 Februari pukul 8 malam waktu tempatan di Aung Mingalar Quarter di Daerah Akyab, Arakan. Ini bermula dengan sekumpulan penunjuk perasaan yang berang menyerang sami Buddha dan merompak seorang remaja wanita. Apabila suaminya menentang serangan itu, jumlah penunjuk perasaan bertambah. Kebanyakan sami keluar dari kuil dan biara selain penduduk tempatan Buddha dengan bersenjatakan pisau, kayu buluh dan senjata bahaya lain bagi memberi sokongan kepada penunjuk perasaan. Malah, mereka bertukar ganas apabila turut membakar rumah-rumah dan mula merompak. Dianggarkan 150 hingga 180 Muslim Rohingya terbunuh dalam insiden itu manakala 500 lagi cedera parah. Turut dilaporkan susulan kejadian itu ialah kehilangan 200 orang termasuk wanita, kanak-kanak manakala selebihnya tinggal sehelai sepinggang kerana peristiwa berkenaan yang dirancang secara rahsia untuk membunuh dan menghapuskan Rohingya. Zinab juga dalam artikel itu menyebut mengenai beberapa buah masjid yang dibakar. Menurutnya, sejurus selepas memulakan pertengkaran mereka kemudiannya mula membakar rumah diikuti kemudiannya masjid dikenali sebagai Mawlik Junction Mosque dan rumah kediaman masing-masing milik Ali Hussain, Aung Thang Thar Tun, Kyaw Sein, Myna, Hla Myint, Mohamed Sultan, Rafique dan Mariam. Dalam insiden itu juga, penunjuk perasaan menahan 10-18 Muslim Rohingya sebagai tebusan kesemuanya remaja manakala 14 hingga 16 tahun. Remaja-remaja berasal dari Gon Boarding tetapi tinggal sebagai pelawat di Buthidaung, Maungdaw dan Kyauktaw turut diculik. Sebelum melakukan jenayah itu, talian telefon dan kemudahan telekomunikasi lain dipadamkan supaya mereka dapat menjalankan misi itu dengan lancar. Anehnya, hanya di kawasan Muslim Rohingya sahaja tidak berfungsi, sebaliknya di tempat-tempat yang dihuni penganut Buddha beroperasi seperti biasa pada hari berkenaan.

63 Laporan Khas "Rohingya Perlu Dibela”, Majalah Milenia, Kuala Lumpur: Yayasan Dakwah Islamiah Malaysia (YADIM) edisi Januari 2008, hlm. 5-13.

64 Dr. Habib Siddiqui dalam kertas kerja dan laporan empat bahagian, “SPDC Military Junta's Crime Against Humanity : Rohingya Refugee Problem" menyebut bahawa dalam tempoh tiga bulan selepas operasi lebih 3,000 orang berlindung di kem pelarian sementara yang dibina kerajaan Bangladesh. UNHCR juga menganggap mereka pelarian tulen dan memulakan operasi bantuan kemanusiaan. Kehadiran mereka dalam jumlah yang begitu ramai selepas apa yang menimpa mereka ini mengundang sorotan antarabangsa khususnya komuniti Muslim. Walaupun kerajaan Myanmar menafikan menindas Rohingya sehingga mengakibatkan mereka terpaksa melarikan diri dan berlindung di Bangladesh tetapi kerajaan menerima mereka semula selepas ditekan 
pihak antarabangsa. Perjanjian dua hala dimeterai pada 9 Julai 1978 di Dhaka di antara Myanmar-Bangladesh sekali gus membawa pulang Rohingya ke kampung halaman mreka pada 1979, selepas sembilan bulan menetap di bumi Bangladesh. Dilaporkan, 2,000 pelarian Rohingya pulang semula manakala lebih 40,000 orang meninggal dunia di kem pelarian. Menurut laporan Human Rights Watch/Asia kira-kira 30,000 pelarian Rohingya masih di Bangladesh dengan sesetengahnya berhijrah ke negara-negara Asia Barat dan selebihnya ke Thailand dan Malaysia. Dr. Habib Siddiqui dalam satu artikel lain, "Just Imagine That You Are Rohingya" yang disiarkan dalam Al-Jazeera News pada April 2006 menyebut bahawa operasi ini juga mengakibatkan kaum Muslimin tanpa terkecuali Rohingya berduyun-duyun melarikan diri untuk berlindung sekali lagi ke Bangladesh. Namun, gelombang kedua menjadi pelarian ini tidak sahaja menumpukan Bangladesh sebagai destinasi tetapi mereka juga mula mengintai ke Thailand, Malaysia dan beberapa negara Asia Barat seperti Emiriyah Arab Bersatu (UAE). Dr. Habib menyebut bahawa lebih 268,000 Rohingya melintasi sempadan Myanmar-Bangladesh selepas operasi dilancarkan. Manakala lebih 3,000 lagi ke Thailand dan Malaysia. Untuk rujukan dan perbincangan lanjut lihat juga artikel oleh Dr. Habib Siddiqui, "The Never-Ending Military Rule In Burma" sebagai satu mesej dalam Campaign Journal for Human Rights of All Ethnics Nationalities In Burma. Artikel penuh boleh diakses di alamat http:/ / www.tayzathuria. org.uk/bd/2006/10/01/hs.htm. Asian Recorder, edisi 5-11 Februari 1992. David L.Steinberg, Burma; The State of Myanmar, Washington DC : Georgetown UP, 2001, hlm. 181. Country Report Thailand/Myanmar, 1993-1994. Asian Recorder, edisi 24-30 Jun 1992.

Far Eastern Economic Review, edisi 4 Mac, 1993. Untuk melihat pernyataan penuh Chris Lewa kepada UNHCR boleh lawati laman web beralamat: http:/ / www.uscirf.gov/events/hearings/2007/ december/120307_saffron6_lewa.

NaSaKa dalam bahasa Burma juga dikenali sebagai "Nay-sat Lu-winmu Sit-say-ye hnin Kut-kwey-hmu Hta-na-gyoke" Ia merupakan pasukan bertindak keselamatan sempadan yang terdiri daripada polis perisikan ketenteraan (MI), Lon Htein (polis antirusuhan), pegawai kastam, imigresen dan Jabatan Tenaga Kerja. Lihat "Burma: The Rohingya Muslim, Ending a Cycle of Exodus? ", Human Right Watch/Asia, New York, September 1996, hlm. 6. Dalam jawapan balas e-mel kepada penulis, Chris Lewa memperincikan lokasi tiga masjid itu sebagai di $D u$ Chee Yar Than, Thin Baw Kway dan Gaw Dhu Thar Ya. Chris boleh dihubungi di alamat chris.lewa@gmail.com. Laporan Khas "Rohingya Perlu Dibela", Majalah Milenia, Kuala Lumpur: Yayasan Dakwah Islamiah Malaysia (YADIM) edisi Januari 2008, hlm. 5-13.

75 Laporan pernyataan Chris Lewa kepada UNHCR. 
76 Laporan Amnesty International, Mei, 2004 . Laporan penuh boleh diakses di laman web Amnesty International di alamat: http:/ / web.amnesty.org/ library.

77 Kebanyakan tahanan politik Myanmar didakwa di bawah undang-undang yang sama di mana ia turut digunakan ke atas Rohingya yang didapati memiliki permit perjalanan yang tamat tempoh. Lihat misalnya, D. Ross and Lawyers Committee for Human Rights, Summary Injustice: Military Tribunal in Burma (Myanmar), New York: 2003, hlm. 40.

78 Laporan Amnesty International, Mei, 2004 . Laporan penuh boleh diakses di laman web Amnesty International di alamat: http:/ / web.amnesty.org/ library.

79 Kebiasaannya, wanita Islam termasuk Rohingya berkahwin apabila baligh, SPDC mengharamkan perkahwinan di bawah umur 18 tahun di Myanmar.

80 Laporan pernyataan Chris Lewa kepada UNHCR pada 2007.

81 Laporan Khas "Rohingya Perlu Dibela", Majalah Milenia, Kuala Lumpur: Yayasan Dakwah Islamiah Malaysia (YADIM) edisi Januari 2008, hlm. 5-13.

82 Kyat ialah mata wang rasmi Myanmar. Asasnya, 6 kyat bersamaan satu dolar Amerika tetapi memandangkan tiada peraturan khususnya secara tidak rasmi kadang-kadang 800 hingga 1,000 kyat nilainya sama seperti satu dolar Amerika.

83 Laporan pernyataan Chris Lewa kepada UNHCR pada 2007. 